\title{
Okul Öncesi Öğretmenlerinin Çocuk İstismarı ve İhmaline Yönelik Algıları*
}

\author{
Preschool Teachers' Perceptions about Child Abuse and \\ Neglect
}

\author{
Yeliz ERDOĞAN**, Durmuş ASLAN***
}

\begin{abstract}
Öz: Bu araştırma, okul öncesi öğretmenlerinin çocuk istismarı ve ihmalini nasıl algıladıklarını belirlemek amacıyla gerçekleștirilmiştir. Araştırma, Gaziantep il merkezinde görev yapan 36 okul öncesi öğretmeninden oluşan çalışma grubuyla gerçekleştirilmiştir. Araştırmada, derinlemesine bir anlayışa sahip olmak amacıyla olgu bilim deseni tercih edilmiş ve nitel veri toplama araçlarından biri olan yarı yapılandırılmış görüşme formu kullanılmıştır. Görüşme formu, okul öncesi öğretmenlerinin çocuk istismarı ve ihmalini nasıl algıladığını belirlemeye yönelik soruları içermektedir. Veriler, öğretmenlerle yapılan bireysel görüşmelerle elde edilmiștir. Elde edilen nitel verilerin analizinde içerik ve betimsel analiz kullanılmıştır. Araştırma sonucunda elde edilen bulgular doğrultusunda, okul öncesi öğretmenlerinin çocuk istismarı ve ihmaline yönelik algıları, alan yazında istismar ve ihmal türleri olarak yer alan altı kategori altında incelenmiştir. Okul öncesi öğretmenlerinin çocuk istismarı ve ihmali konusunda duyarlılık gösterdikleri ve bir takım bilgilere sahip oldukları fakat bu bilgilerin yetersiz olduğu görülmüştür. Ayrıca, öğretmenlerin, çocukların daha çok ev ortamında, bakımından sorumlu ve yakınındaki kişiler tarafından istismar ve ihmale uğradıklarını düşündükleri belirlenmiştir. Son olarak, katılımcıların istismarı ihmalden daha iyi tanımladıkları sonucuna ulaşılmıştır.
\end{abstract}

Anahtar Kelimeler: Okul öncesi öğretmeni, çocuk, istismar, ihmal

\begin{abstract}
This research was conducted to determine how preschool teachers perceive child abuse and neglect. The research was carried out with 36 preschool teachers working in preschool education institutions in in the center of Gaziantep. In the study, phenomenological design were preferred and semistructured interview form, one of the qualitative data collection tools, were used to deep and detailed understanding. The interview form includes questions to determine how preschool teachers perceive child abuse and neglect. Data were obtained through interviews with teachers. Content and descriptive analysis were used in the analysis of the qualitative data obtained. According to the findings of the research, the perceptions of preschool teachers towards child abuse and neglect were examined under the six categories of abuse and neglect in the literature. Preschool teachers had some knowledge and sensitivity about child abuse and neglect, but their knowledge was insufficient. Moreover, it was found that teachers believed that children are often abused and neglected by people responsible for their care. Finally, it was found that the participants defined abuse better than neglect.
\end{abstract}

Keywords: Preschool teacher, child, abuse, neglect

\section{Giriş}

Bir toplumun geleceğini sağlam zeminler üzerinde kurabilmesi ve ilerleme gösterebilmesi için çocukların bedensel, ruhsal ve fiziksel olarak sağlıklı bir şekilde büyümesi gerekmektedir. Bireyin büyüme, gelişme, olgunlaşma ve kişilik gelişiminin önemli bir evresini teşkil eden okul öncesi yılları sağlıklı ve verimli bir şekilde geçirebilmesi, ailede verilen eğitimin yanı sıra nitelikli bir okul öncesi eğitimi ile mümkün olmaktadır. Bu açıdan, istismar türlerinin önlenmesinde okul

\footnotetext{
* Birinci yazarın hazırladığı “Okul Öncesi Ö̆ğretmenlerinin Çocuk İstismarı ve İhmali ile İlgili Algıları” başlıklı yüksek lisans tezinden üretilmiştir.

** Bilim Uzmanı, Çukurova Üniversitesi, Eğitim Fakültesi, Adana-Türkiye, ORCID: 0000-0003-0061-9746, e-posta: yyondemer@hotmail.com

*** Doç. Dr., Çukurova Üniversitesi, Eğitim Fakültesi, Adana-Türkiye, ORCID: 0000-0001-5204-7749, e-posta: asland@cu.edu.tr
} 
öncesi eğitim kurumlarının, özellikle de okul öncesi öğretmenlerinin önemli rolü bulunmaktadır (Baginsky, 2003). Çocuklarla aileleri dışında en fazla vakit geçiren kişiler olmalarından dolayı, istismar ve ihmale uğrayan çocukları belirlemede ve onları korumaya yönelik tedbir almada öğretmenlere kritik görevler düşmektedir (Erol, 2007).

Günümüzde çocuğa yapılan istismar ve ihmalin tanımlanması, şekli ve ne kadar sıklıkta karşılaşıldığı dünya çapında farklılık göstermekle birlikte, varlığını sürdürmeye devam eden bir olgu olarak karşımıza çıkmaktadır. Çocuk istismarı ve ihmali, çoğunlukla çocuğun tanıdığ bireyler tarafından yapılması ve tekrarlanması, kimi zaman şiddetlenerek devam etmesi ve çeşitli biçimlerde gerçekleşmesi nedeniyle, çocukluk döneminde tedavisi en zor psikolojik ve travmatik vakalardan biri olarak kabul edilmektedir (Johnson, 1996). İlgili alanyazında, çocuk istismarının çeşitli tanımları bulunmaktadır. Dünya Sağlık Örgütü çocuk istismarını, çocuğun sağlığına, fiziksel ve psiko-sosyal gelişimine olumsuz olarak tesir eden ve bir şahıs, toplum ya da ülke tarafından kasıtlı veya kasıtlı olmayan bir biçimde yapılan davranışlar olarak tanımlamaktadır (Polat, 2005). Çocuk istismarının üç türü bulunmaktadır. Bunlar, fiziksel, duygusal ve cinsel istismardır. Wekerle, Miller, Wolf ve Spindel (2006) fiziksel istismarı, çocuğun bedeninin herhangi bir kısmına yönelik olarak kasıtlı bir biçimde gerçekleştirilen ve zarar verme şeklinde sonuçlanan güç kullanma davranışı olarak tanımlamaktadır. Bu istismar türü zehirleme, yakma, su altında tutma, tekmeleme, sarsma, zarar verici kuvvet uygulama şeklindeki davranışları kapsamaktadır. Duygusal istismar ise, ebeveynler veya çevresindeki diğer yetişkinlerin çocuğun yeteneklerinin üzerinde istek ve beklenti amaçlayarak saldırganca davranmaları şeklinde tanımlanmaktadır (Runyan, Wattam, Ikeda, Hassan ve Ramiro, 2002). Cinsel istismarı ise, Kutchinsky (1991), bilinçli bir kişi ya da yaşça daha yetişkin bir birey tarafından cinsel haz elde etmek maksadıyla çocuğun istismar edilmesi şeklinde açıklamaktadır.

Çocuk ihmali ise, çocuktan sorumlu bireylerin, çocuğun beslenme, barınma, sağlik, gözetim gibi hayati ihtiyaçlarını yeterince sağlayamaması olarak ifade edilmektedir (Kara, Biçer ve Gökalp, 2004). İhmal de, tıpkı istismar gibi fiziksel, duygusal ve cinsel boyutları içermektedir. Fiziksel ihmal, çocuğun beslenme, giyinme, barınma ve tıbbi ihtiyaçlarını karşılamakta yoksun bırakma ya da yetersiz şekilde karşılama şeklinde tanımlanmaktadır (Erermiş, 2001). Duygusal ihmal ise, uygulanan ya da uygulanması gerektiği halde ihmal edilerek ergen ve çocukların ruhsal yönlerinin suistimal edilmesine yol açan, çevresel ve bilime dayanan ölçütlere göre ruhsal bakımdan hasar veren davranış şekilleri olarak ifade edilmektedir (Polat, 2001). Son olarak, cinsel ihmal, çocukların cinsel açıdan sömürülmelerine karşı gerekli önlemlerin alınmaması ve korunmalarına yönelik duyarsız olunması, cinsel gelişimlerine gerekli önem ve özenin gösterilmemesi şeklinde açıklanmaktadır (Reece, 1997).

İstismar ve ihmal, birbirine yakın ancak farklı kavramlardır. İstismarın ihmalden farklı yanı, istismarın etkin, ihmalin edilgen olmasıdır. Günümüzde, özellikle gelişmiş ülkelerde çocuk sağlığı ve gelişimi ile ilgili ciddi çalışmalar yapılmasına rağmen çocukların hala çeşitli istismar ve ihmallerle karşı karşıya kaldığı görülmektedir. Öte yandan, toplumun temel yapısını oluşturan ve savunmasız bir durumda olan çocukların, yakınındaki ya da yabancı kişiler tarafından ihmal ve/veya istismar edilmesi, kabul edilemez bir durumdur (Gökler, 2006).

İstismara ve ihmale uğrayan çocuk vakaları asırlardır tüm toplumda yer almakla birlikte ne yazık ki çocuk sağlığı problemi olarak ancak son yıllarda ele alınmaya başlanmıştır. Amerika Birleşik Devletlerinin Colorado ve Kuzey Carolina eyaletlerinde yapılan bir çalışmada, çocuğa yönelik uygulanan ihmal ve istismar vakalarında can kayıplarının \% 50-60 oranında tespit edildiği ve çoğu vakanın resmi verilerde yer almadığı tespit edilmiştir (Herman ve diğerleri, 1999). Asya ve Avrupa'nın çeşitli ülkelerinde yapılan diğer bir araştırmada ise, 9-17 yaş arasındaki her 10 çocuktan 6'sının hatalı davranışlar sergiledikleri gerekçesiyle, ebeveynleri tarafından şiddete maruz kaldıkları belirlenmiştir (Akt. Polat, 2005). Theoklitou, Kabitsis ve Kabitsi'nin (2012) ilkokul öğrencilerine yönelik okul ortamında istismar ve ihmali araştırdıkları çalışmada ise, araştırmaya katılan bireylerin \%53'nün ihmale, \%33'ünün duygusal istismara ve \%10'unun fiziksel istismara maruz kaldıkları tespit edilmiştir.

Ülkemizde ise, UNICEF ve Sosyal Hizmetler ve Çocuk Esirgeme Kurumu'nun 2008 yılında yaptıkları ve 2010 yılında yayınladıkları Aile İçi Şiddet Araştırması verilerine göre, yedi- 
on sekiz yaş aralığındaki çocukların \% 51'i duygusal istismara, \% 45' i fiziksel istismara, \% 25'i ise ihmale maruz kalmaktadır. Öte yandan, ülkemizde gerek çoğunlukla tanısının konulamamasından gerekse de çocukların istismar ve ihmal durumunda her zaman başvurabileceği bir yer bulunamamasından dolayı tam anlamıyla gerçek rakamlar belli değildir. Ayrıca ülkemizde çocuk istismarı vakalarının oranı, dünya ortalamasının çok üzerinde bulunmaktadır. Karşılaştığı şiddet sonucunda yaralanan ve güvenlik birimine bildirilen 0-17 yaş arasındaki çocukların sayısı 2014 yılında 74.064 iken 2016 yılında bu sayı 83.552'ye yükselmiştir (Türkiye'de Çocuk İstismarı Raporu, 2018).

Çocukları istismar ve ihmalden koruma çalışmaları zor, sıkıntılı, stresli ve bu konuda bilgi ve yetenek sahibi olmayı gerektiren bir uğraştır. Çocukların aileden sonra en fazla vakit geçirdikleri mekân okullarıdır. Aile içerisinde yaşananlardan etkilenen çocuk, bunu beraberinde okula getirebilmektedir. Bu durumda, aile içinde olumsuzluklar yaşayan çocuğun durumunu fark edip harekete geçmesi beklenen ilk kişi öğretmenidir (Erginer, 2007). Eğitimcilerin bu ciddi görevlerini doğru şekilde yerine getirmeleri durumunda, öğrenciler kötü durumlarla karşılaştıklarında ya da kendilerini emniyetli hissetmediklerinde, çoğunlukla öğretmenleriyle paylaşımda bulundukları görülmektedir. Öğrenciler, özellikle aile içinde yaşadıkları cinsel vakaları eğitimcilerine açılarak anlatabilmektedirler. Bu nedenle, eğitimcinin öğrencisi tarafından paylaşılan böylesi bir durum sonrasında nasıl bir yol izlemesi gerektiğini bilmesi mühim bir konudur (Kenny ve McEachern, 2008). Çocuk istismarı ve ihmali konusunda yeterli donanıma sahip bir eğitimci, öğrencisinin herhangi bir yerinde gördüğü yara, çizik ve benzeri emareler ile ilgili ne olup bittiğini öğrenerek tespitte bulunabilir. Ayrıca öğretmen öğrencisinin akademik başarısında düşme, saldırgan davranışlar, dikkat dağınıklığı, keyifsizlik gibi ani davranış değişikliklerini gözlemleyerek sorunu araştırma yollarına gidebilir (Beyazova ve Şahin, 2001).

Çocuk istismarı ve ihmali, uzun yıllardır araştırmacıların önemle üzerinde durdukları bir konudur. Uluslararası alanyazın incelendiğinde, öğretmenlerin çocuk istismarı ve ihmaline ilişkin deneyimleri ve görüşleri (Toros ve Tiirik, 2006; Walsh ve Farrell, 2008) ile istismarın öğretmenler tarafindan bildirim ve rapor edilme durumlarına (Kenny, 2001; O'Toole, Webster, O'Toole ve Lucal, 1999; Toros ve Tiirik, 2006) ilişkin çalışmaların yer aldığı görülmektedir. Söz konusu araştırmaların sonuçları, eğitimcilerin çocuk istismarı ve ihmaline ilişkin var olan bilgi ve tecrübelerinin yeterli seviyede olmadığını ayrıca farkındalık ve bildirimde bulunma noktasında kendilerini yetersiz hissederek bu konuda güven problemi yaşadıklarını göstermektedir. Öğretmenlerin ya da okul personelinin öğrenciye yönelik istismar ve ihmal davranışlarına ilişkin yapılan araştırmalar ise (Benbenishty, Zeira ve Astos, 2002; Khoury-Kassabri, 2009; Kim ve diğerleri, 2000; Theoklitou ve diğerleri, 2012) öğrencilerin okul çalışanları tarafindan istismara maruz kalmalarının sık karşılaşılan bir durum olduğunu ortaya koymaktadır.

Ülkemizde yapılan çalışmalar incelendiğinde ise, okul öncesi öğretmenlerinin çocuk istismarı ve ihmaline yönelik farkındalıklarını belirlemek amacıyla bir takım araştırmalar (Dönmez, 2009; Erol, 2007; Sarıbaş, 2013; Tugay, 2008) yapıldığ1 görülmektedir. Söz konusu araştırmaların bulgularına göre, okul öncesi öğretmenlerinin çocuk istismarı ve ihmaline yönelik yeterli bilgiye sahip olmadıkları ve bildirime ilişkin eksikliklerinin yer aldığı ortaya çıkarılmıştır. Söz konusu çalışmalarda, veri toplama yöntemi olarak çeşitli anketler kullanılmıştır. Böylesi bir yöntem daha geniş örneklemlerden veri toplamaya imkân vermekle birlikte, derinlemesine bilgi edinmede bazı sinırlılıklara sahiptir. Bu nedenle, Kefeli (2016) okul öncesi eğitim kurumları personelinin çocuk istismarı ve ihmali hakkındaki görüşleri ve okul öncesi eğitimcilerinin sınıf ortamında çocuğa ilişkin istismar ve ihmal hareketlerini tespit etmek amacıyla, gözlem ve görüşmeye dayalı bir çalışma gerçekleştirmiştir. Araştırma sonucunda, okul personelinin çocuk istismarı ve ihmaline ilişkin gerekli bilgi düzeyine sahip olmadıklarını, okul öncesi öğretmenlerinin ise istismara ilişkin düşünceleri ile sınıf ortamındaki davranışlarının çeliştiği sonucuna ulaşmıştır.

Öte yandan, çocuk istismar ve ihmali ile karşlaşma oranı, okul öncesi yıllarda daha büyük yaş gruplarına oranla iki kat daha fazladır (WHO, 2002). Bu nedenle, okul öncesi ögretmenlerinin bu problem üzerindeki farkındalıkları oldukça önemlidir. Okul öncesi ögretmenlerinin çocuk istismarı ve ihmali konusunda bilgilendirici ve önleyici danışmanlık 
verilmesi, onların çocuk istismarı ve ihmalinin engellenmesinde, erken tanılamada ve vaka durumuyla karşılaşıldıklarında, söz konusu durumla etkin şekilde başa çıkmalarında önemli bir rol oynayabilmektedir. Böylesi bir faaliyetin gerçekleştirilebilmesi için de öncelikle öğretmenlerin çocuk istismarı ve ihmaline yönelik mevcut algılarının bilinmesi gerekmektedir. Ülkemizde, okul öncesi öğretmenlerinin çocuk istismarı ve ihmali ile ilgili algılarını ortaya koymaya yönelik nitel çalışmaların sınırlılığı göz önünde bulundurularak, bu çalışmada, okul öncesi öğretmenlerinin çocuk istismarı ve ihmali ile ilgili algıları belirlenmeye çalışılmıştır.

\section{Araştırmanın amacı}

$\mathrm{Bu}$ araştırmanın genel amacı, çocuk istismarı ve ihmaline ilişkin okul öncesi öğretmenlerinin algılarının incelenmesidir. Bu temel amaç çerçevesinde aşağıdaki sorulara yanıt aranmıştır:

1. Okul öncesi öğretmenleri fiziksel istismarı nasıl algılamaktadırlar?

2. Okul öncesi ögretmenleri duygusal istismarı nasıl algılamaktadırlar?

3. Okul öncesi öğretmenleri cinsel istismarı nasıl algılamaktadırlar?

4. Okul öncesi öğretmenleri fiziksel ihmali nasıl algılamaktadırlar?

5. Okul öncesi öğretmenleri duygusal ihmali nasıl algılamaktadırlar?

6. Okul öncesi öğretmenleri cinsel ihmali nasıl algılamaktadırlar?

\section{Yöntem}

Okul öncesi öğretmenlerinin çocuk istismarı ve ihmaline yönelik algılarını ortaya koymayı amaçlayan bu çalışmada nitel araştırma desenlerinden olgu bilim (fenomenoloji) deseni kullanılmıştır. Olgu bilim deseni (fenomenoloji), içinde farkındalıkların yer aldığı, ancak hakkında detaylı ve içeriğine inen bir kavrayışa sahip olunmayan olgulara tüm dikkati verme olarak tanımlanmaktadır (Yıldırım ve Şimşek, 2008). Olgu bilim deseninin amacı, araştırmada yer alan kişilerin içinde bulundukları hayata dair bakış açıları ve tecrübeleri ile ilişkilendirdikleri kişisel anlamları ortaya koymaktır (Johnson ve Christensen, 2008). Bu çalışmada, okul öncesi öğretmenlerinin çocuk istismarı ve ihmalini nasıl kavradıklarına, anladıklarına, anlamlandırdıklarına ve yorumladıklarına yönelik algıları ortaya çıkarılmaya çalışıldığından, fenomenoloji desen tercih edilmiştir. Araştırma sorularına derinlemesine cevap bulmak amaciyla nitel araştırma tekniklerinden biri olan, yarı yapılandırılmış görüşme tekniği kullanılmıştır.

\section{Çalışma grubu}

Araştırmanın çalışma grubunu, Gaziantep il merkezinde görev yapmakta olan 36 okul öncesi öğretmeni oluşturmaktadır. Fenomoloji çalışmalarında, olguyu açıklayacak katılımcıların olguyu aktarabilecek birincil kişilerden oluşması ve bu bireylerin dikkatli bir şekilde seçilmesi gerekmektedir (Creswell, 2007; Patton, 2014). Bu nedenle, çalışmada farklı görüşlere ulaşmak için çeşitli okullarda çalışan farklı kıdem yıllarına sahip 36 okul öncesi öğretmenine ulaşılmıştır. Araştırmada amaçlı örnekleme yöntemlerinden biri olan maksimum çeşitlilik yöntemi kullanılmıştır. Kişilerde değişiklik gösteren kimi kriterlerin önceden belirlenmesi ve ardından kriterlere göre olabildiğince çeşitlilik ortaya koyan katılımcıların seçimini içeren bu yöntemde (Creswell, 2007) amaç, soruna dâhil olabilecek katılımcıların türünü en üst seviyede ortaya koymaktır (Yıldırım ve Şimşek, 2008). Bu araştırmada, katılımcıların öğretmenlik görevindeki sürelerinin, çalıştıkları eğitim kurumlarının türünün ve sosyo-ekonomik düzeylerinin çeşitlilik göstermesine özen gösterilmiştir. Katılımcılar hakkındaki bilgiler tablo 1'de verilmiştir.

Tablo 1'de de görüldügüü üzere, çalışma grubunda yer alan öğretmenlerin 8'inin (\%22) 05 y1l aras1, 10'unun (\%28) 6-10 yıl aras1, 11'inin (\%31) 11-15 y1l aras1 ve 7'sinin (\%19) 16-20 yılları arasında kıdeme sahip oldukları görülmektedir. Öğretmenlerin çalıştıkları okulların bulunduğu çevrenin sosyo-ekonomik durumuna bakıldığında ise, öğretmenlerin 12'sinin (33) düşük, 14'ünün (\%39) orta ve 10'unun (28) ise yüksek seviyedeki bölgelerde yer alan okullarda görev yaptıkları belirlenmiştir. Katılımcıların 32'si kadın (\%89), 4'ü (\%11) erkektir. 19 öğretmen anaokulunda görev yapmakta iken (\%53), 17 öğretmen ise anasınıfında görev yapmaktadır (\%47). 
Tablo 1

Çalışma Grubuna Alınan Okul Öncesi Öğretmenlerine İlişkin Bilgiler

\begin{tabular}{llcl}
\hline \multicolumn{2}{c}{ Değişkenler } & $\mathrm{f}$ & $\%$ \\
\hline \multirow{3}{*}{ Görev süresi } & $0-5$ yıl arası & 8 & 22 \\
& 6-10 yıl arası & 10 & 28 \\
& $11-15$ yıl arası & 11 & 31 \\
& $16-20$ yıl arası & 7 & 19 \\
\hline \multirow{2}{*}{ Cinsiyet } & Kadın & 32 & 89 \\
& Erkek & 4 & 11 \\
\hline \multirow{2}{*}{ Görev yapılan okulun bulunduğu } & Düşük & 12 & 33 \\
çevrenin sosyo-ekonomik durumu & Orta & 14 & 39 \\
& Yüksek & 10 & 28 \\
\hline \multirow{2}{*}{ Görev yapılan okulun türü } & Bağımsız anaokulu & 19 & 53 \\
& İlkokula bağlı anasınıfı & 17 & 47 \\
\hline
\end{tabular}

\section{Veri toplama aracı}

Araştırmada veri toplama aracı olarak araştırmacılar tarafından hazırlanan yarı yapılandırılmış görüşme formu kullanılmıştır. Nitel veri sağlayan bir araç olarak yarı yapılandırılmış görüşme, açık uçlu soruların yer aldığı bir tekniktir. Katılımcıların bir konu ile ilgili hislerini, mantıklarını, bilgi düzeylerini ve fikirlerini ayrıntılı olarak incelemektedir (Johnson ve Christensen, 2008). Bu bağlamda, uygun görüşme soruları hazırlayabilmek amacıyla kapsamlı bir alan yazın incelemesi yapılmıştır. Alan yazın çalışması sonucunda, altı genel tema saptanmış ve bu genel temaların paralelinde yedi sorudan oluşan bir yarı yapılandırılmış görüşme formu oluşturulmuştur. Görüşme formunda, okul öncesi öğretmenlerinin çocukların fiziksel, duygusal, cinsel istismar ve ihmaline yönelik algılarını ortaya koymaya ilişkin sorulara yer verilmiştir. Hazırlanan form, görüşlerini almak üzere, okul öncesi eğitimi ve nitel araştırma konularında uzman üç öğretim üyesine sunulmuştur. Uzman görüşü ve araştırmanın amacı doğrultusunda görüşme soruları tekrar düzenlenmiştir. Bir sonraki adımda ise, görüşme formundaki soruların anlaş1lırlığının ve uygunluğunun değerlendirilmesi amacıyla iki okul öncesi öğretmenine pilot uygulama yapılarak görüşme formuna son hali verilmiştir.

\section{Verilerin toplanması}

Araştırma kapsamında, Gaziantep İl Milli Eğitim Müdürlüğü Ar-Ge biriminden araştırmanın yapılabilmesine yönelik araştırma izninin alınmasının ardından, araştırmacı tarafından Şehitkâmil ve Şahinbey ilçe merkezlerindeki üç tip sosyo-ekonomik seviyeye ait okullar Milli Eğitim Bakanlığı'nın belirlediği hizmet alanlarına göre ve alan taraması sonucunda belirlenmiştir. Bu okullarda görev yapan okul öncesi öğretmenlerinden gönüllülük esasıyla araştırmaya katılmak isteyen kişiler arasından amaçlı örnekleme yöntemiyle seçilenlerle görüşülerek görüşme tarihleri ve saatleri belirlenmiştir. Görüşmeler öğretmenlerin görev yaptıkları okulların uygun bir ortamında bireysel olarak gerçekleştirilmiştir. Görüşülen ortamların aydınlık ve ferah olmasına, görüşmecinin dikkatinin dağılabileceği herhangi bir durumun olmamasına dikkat edilmiştir. Katılımcılara araştırma etiği kapsamında kişisel bilgilerinin ve görüşmeden elde edilen verilerin sadece araştırma için kullanılacağı bilgisi verilmiştir. Ayrıca araştırma sonuçlarının güvenilirliğini sağlamak amacıyla ses kaydı alınacağı belirtilmiş ve izinleri istenmiştir. Görüşme yapıldıktan sonra kısa bir özetleme yapılarak yanıtlayıcıların cevaplarına ilişkin teyidi alınmıştır. 


\section{Verilerin analizi}

Araştırma kapsamında elde edilen görüşme verilerinin analizi, nitel veri analizlerinden içerik ve betimsel analiz kullanılarak yapılmıştır. Ses kayıt cihazından elde edilen verilerin yazılı formata dönüştürülmesi ile toplam 370 sayfa ham veri elde edilmiştir. Toplanan görüşme kayıtları "içerik analizi" yöntemiyle analiz edilmiştir. Bu yönteme göre, elde edilen birbirine benzer veriler, belirli kavram ve kategoriler çerçevesinde yan yana getirilerek düzenlenmiş ve yorumlanmıştır (Yıldırım ve Şimşek, 2008). Kodlar altı ana kategorinin altına yerleştirilerek baştan sona okunmuş ve alt kategoriler ile ilgili fikir oluşturulmaya çalışılmıştır. Birbiriyle ilişkili olan kodların bir araya gelmesiyle 86 sayfalık kod defteri önce 54 sayfaya inmiş ardından da 38 sayfaya düşmüştür. Bilgisayar ortamında oluşturulan kod defteri birkaç kez tarandıktan sonra ana kategorilerin alt kategorileri oluşturulmuş kelime, cümle ve paragrafları bir araya getirilmiştir. Toplanan verilerin analizi sonucunda elde edilen bulguların yorumlanması sürecinde, katılımc1 ifadelerinden doğrudan alıntılara yer verilerek bulguların kendi içerisinde bütünsel olarak anlamlı ve tutarlı olup olmadığı incelenmiştir. Bulguların yorumlanmasında var olan durumu en sade şekilde betimlemek amacıyla doğrudan alıntılara yer verilirken öğretmenler için "Ö1-Ö36" şeklinde kodlamalar kullanılmıştır. Öğretmenlere verilen kodlamalar, alıntının sonunda parantez içerisinde belirtilmiştir.

\section{Geçerlik ve güvenirlik}

Bilimsel çalışmaların ölçütlerinden en önemlisi sonucun inandırıcılığıdır. Araştırma sonuçlarının inandırıcılığını sağlamada en fazla kullanılan iki ölçüt geçerlik ve güvenirliktir (Yıldırım ve Şimşek, 2008). Güvenirliğin tanımı alan yazında tutarlılık ve sağlamlık şeklinde açıklanırken, geçerlik doğruluk olarak yer almaktadır (Neuman, 2007). Araştırmacının, katılımcıları nasıl seçtiği, katılımcı sayısı ve özellikleri, katılımcıların araştırmaya yönelik bilgileri, kullanılan veri toplama ve analiz teknikleri hakkında ayrıntılı bilgilerin yer alması gerektiğinin önemi nitel araştırmalarda özellikle vurgulanmaktadır (Johnson, 1997). Araştırmanın geçerlik ve güvenirliğinin diğer bir ayağı ise araştırmanın denetlenebilirliğidir. Çalışmanın kısa zamanda denetlenebilirliğini sağlamak için araştırma sürecinin anlaşılır ve açık şekilde ortaya konması gerekmektedir (Yıldırım, 2010). Araştırmanın süreci açık şekilde tanımlanarak, gerekli bölümlerde süreç tablolarla desteklenerek anlatılmıştır. Ayrıca araştırmanın geçerliğini arttırmak için bulgularda doğrudan alıntılardan yararlanılarak sürecin detayları ortaya konmuştur.

\section{Bulgular}

$\mathrm{Bu}$ araştırmanın amacı, okul öncesi öğretmenlerinin çocuk istismarı ve ihmaline yönelik algılarının neler olduğunu ortaya koymaktır. $\mathrm{Bu}$ algılar, araştırma soruları çerçevesinde sunulmuştur.

\section{Okul öncesi öğretmenlerinin fiziksel istismara yönelik algıları}

Araştırmanın birinci sorusu, okul öncesi öğretmenlerinin fiziksel istismara yönelik algılarının ne olduğu yönündedir. Araştırma bulgularına göre, örneklemdeki okul öncesi öğretmenlerinin fiziksel istismara yönelik algıları iki alt kategoriden oluşmaktadır. Bunlardan ilki gücü kötüye kullanarak saldırıda bulunma, diğeri ise bir araç vasıtasıyla saldırıda bulunmadır. Öğretmenlerin fiziksel istismara yönelik algılarına ilişkin kategoriler Şekil 1'de verilmiştir. 


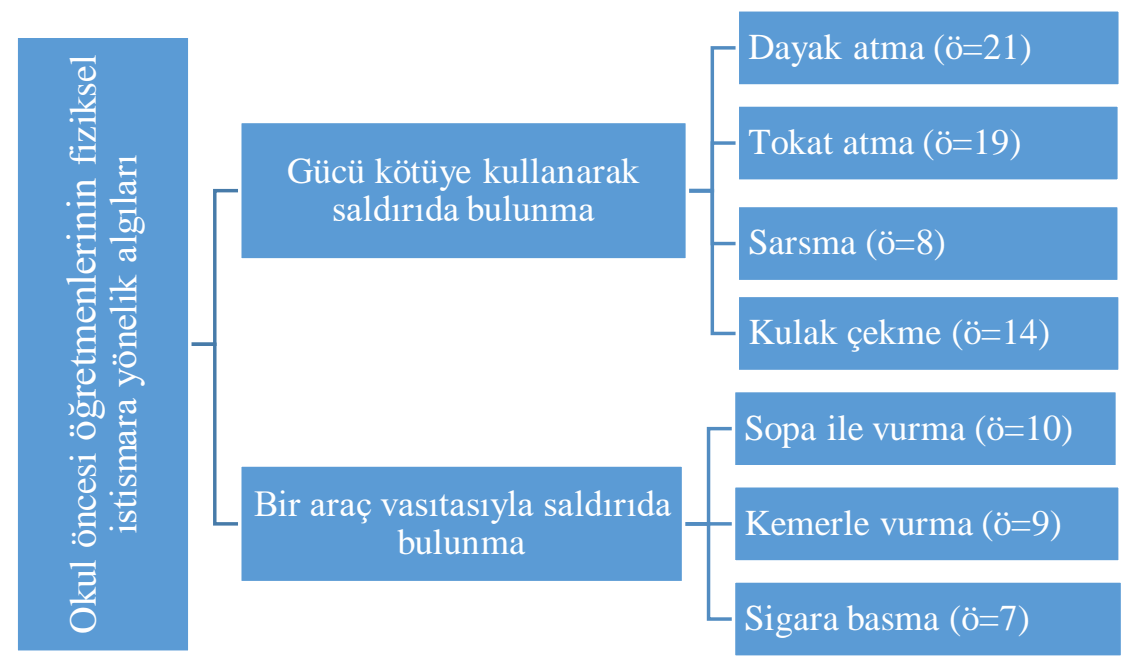

Şekil 1. Okul öncesi öğretmenlerinin fiziksel istismara yönelik algıları

(ö: ilgili cevabı veren öğretmen sayısı)

\section{Gücü kötüye kullanarak saldırıda bulunma}

Öğretmenler, birey ya da bireylerin gücünü kötüye kullanarak çocuğa dayak atma, dövme, tokat atma, sarsma ve kulak çekme şeklinde zarar verici davranışlarda bulunmasını, fiziksel istismar olarak algıladıklarını dile getirmişlerdir. Ayrıca, çocuktan daha güçlü olan bireylerin kızdıklarında bu tür davranışları kolaylıkla uyguladıklarını ifade etmişlerdir.

Dayak atma

Dayak atma davranışını okul öncesi öğretmenleri, çocuktan güçlü birey ya da bireyler tarafindan çocuğun bedenine yönelik yapılan ve yaygın olarak görülen bir şiddet türü olarak yorumlamakta ve fiziksel istismarın bir parçası olarak görmektedirler.

"Fiziksel istismar deyince benim aklıma ilk olarak dayak geliyor, çünkü büyüklerin çocuklar üzerinde en fazla gü̧̈ uyguladı̆̆ fiziksel şiddetin bu olduğunu düşünüyorum” $(O ̈ 11)$.

"Bir çocuğun kendinden daha güçlü biri tarafindan evde, sokakta, okulda dayak yediğini, dövüldüğ̈̈nü, ona vurulduğunu gördüğ̈̈mde böyle durumlar fiziksel istismardır" (Ö17).

Tokat atma

Tokat atma davranışı ile ilgili olarak okul öncesi öğretmenleri, çocuğun yakınları tarafından yapılmış olsa bile, böylesi bir eylemin gerekçesi olmadığını ve şiddet uygulanmasından dolayı fiziksel istismar davranışı olarak değerlendirdiklerini ifade etmişlerdir.

"Yolda giden annelerin bir anda çocuğa en basitinden tokat atması, benim en çok aklımda kalan senaryodur. Mutlaka herkes bir yerlerde bir çocuğun anne ya da babası tarafindan herkesin içinde bir tokat yediğine şahit olmuştur. Bunda her türlü şiddet uygulanıyor, dolayısıyla istismardır. Çünkü çocuğa şiddet uygulayarak saldırlda bulunuyorsunuz" (Ö2).

"Çocuğa bir hata yaptığında, sebebi ne olursa olsun, tokat atmayı doğru bulmuyorum ben. Yetişkinler bunu çok fazla yapıyor ama çocuk hem bedensel hem de duygusal olarak istismara maruz kalmış oluyor" (Ö12). 
Sarsma

Sarsma davranışı ile ilgili olarak ise öğretmenler, toplum nazarında çok fazla dikkate alınmamasına ve basit bir şiddet türü olarak değerlendirilmesine rağmen, bu davranışın doğru olmadığını ve fiziksel istismar olarak değerlendirdiklerini ifade etmişlerdir.

"Mesela kafasindan tutup çocuğu sarsmak; omzundan, kolundan tutup sallayıp sarsmak gibi davranışlar yapıllyor. Ögretmen kolundan tutup sarsarak sandalyeye oturtuyor. Evet, burada çocuğun hem bedenine hem ruhuna zarar veriliyor. Bu fiziksel istismardır" (Ö4).

Kulak çekme

Kulak çekme davranışını okul öncesi öğretmenleri, sebebi ne olursa olsun çocuğun canını acıtan, onun bedenine zarar veren ve ruhen hoşuna gitmeyecek bir davranış olarak görmekte ve fiziksel istismar olarak yorumlamaktadırlar.

"Sen bu çocuktan daha güçlüsün ve bu gücünü kötüye kullaniyorsun, örneğin kulağını çekiyorsun. Bu çocuğun sana gücü yetmiyor, ama senin çocuğa gücün yetiyor. Burada bir istismar söz konusu” (Ö3).

"Fiziksel istismar, güçlü birinin güçsüze, gücünün yettiği birine karşı sinirlendiğinde fiziksel şiddette davrandığı şekildir. Mesela sinıfta yaramazlık yapıyorsa hangi nedenle olursa olsun vurmak, kulağından çekmek çok yanlış davranışlar” (Ö6).

Öte yandan, bazı okul öncesi öğretmenleri, eğer kulak çekme davranışı çocuğun sadece kulağından tutarak, bir güç uygulamadan, canını acıtmadan, uyarı amacıyla yapılıyorsa bunun bir istismar olmadığını ifade etmişlerdir.

"Mesela, çocuğun kulağından onu ikaz etmek amacıyla, canını acıtmadan tutabiliriz. Bunun fiziksel istismar olduğunu düşünmüyorum ama kulağını klzartacak şekilde acıtarak yaparsanız işte o zaman istismar olur" (Ö9).

"Yani şöyle bir kulağını tutar gibi yapıp, tutarak çekmeden, ben senin bu hareketine sinirlendim mesajını vermek istismar değildir. Ama böyle şiddetli şekilde kulağını bütün bir gücünle çekmek istismardır” (Ö3).

\section{Bir araç vasıtasıyla saldırıda bulunma}

Öğretmenlerin fiziksel istismar algılarına ilişkin ikinci alt kategori, çocuğa bir araç vasıtasıyla saldırıda bulunma davranışıdır. Öğretmenler, günümüzde halen varlığını sürdüren ve birey ya da bireyler tarafindan çocuğun bedenine sopayla vurma, kemer ile dövme ve bedenin herhangi bir yerine sigara basma gibi bir araç kullanarak şiddet uygulama davranışının fiziksel istismar olduğunu belirtmektedirler. Katılımcılar, herhangi bir araç vasıtasıyla şiddet uygulamayı, fiziksel istismar olgusu içerisinde en ağır dereceli zarar verme şekli olarak değerlendirmişlerdir.

\section{Sopa ile vurma}

Sopa ile vurma davranışına ilişkin olarak okul öncesi öğretmenleri, kişinin karşısındakine sopa kullanarak şiddette bulunmasının bir istismar davranışı olduğunu ifade etmişlerdir. Özellikle geleneksel yöntemle sınıf yönetiminin sağlandığı sınıflarda yetişmiş olan katılımcılar, ögretmenlerinin kendilerine sopa ile vurduğunu ve bu durumun unutamadıkları olumsuz bir davranış olarak hafızalarında yer aldığını belirtmişlerdir.

"Sinıfta bir arkadaşımı yaramazlık yapar ya da düzeni bozarsa, öğretmen sinirlenir hepimizin ellerini birleştirip strayla sopayla dayak atardl. Ne kadar yanlış! Ben de ögretmenim. Hiçbir hata genellenir mi? Düşündügüumde bizler de istismara maruz kalmışı" (Ö13). 
"Hani sopalarla sıra dayă̆ yerdik ya. Güya tokat atmıyor hoca! Hiç unutmam gözümü kapatışımı, fiziksel istismardır tabii ki" (Ö18).

Kemerle dövme

Kemerle dövme, okul öncesi öğretmenlerinin fiziksel istismar olarak dile getirdikleri davranışlarından bir diğeridir. Kemerle dövme, çocukların özellikle aile içinde en yakın bireyleri tarafından maruz kaldıkları istismar davranışlarından biri olarak yorumlanmıştır.

"Mesela kemerle dövmek. 'Babam bizi kemerle döverdi', özellikle eski zamanlarla ilgili insanların çok fazla kullandiğı bir cümledir. Çok kötü bir durum. Kesinlikle bana göre bir fiziksel istismar bu" (Ö25).

"Kemerle dövmek örneğin, böyle şeyleri duyuyoruz. Günümüzde çok sık rastlanmasa da özellikle eskiden babalar erkek ve kız çocuklarını kemerleri ile dövermiş. Kesinlikle bana göre bir fiziksel istismar" (Ö33).

\section{Sigara basma}

Sigara basma ile ilgili olarak da okul öncesi öğretmenleri, çocuğun bedeninin herhangi bir yerine sigara basarak yakmanın bir istismar davranışı olduğunu ifade etmektedirler. Ayrıca, bu davranışı diğer istismar türlerine göre en ağır davranış şekli olarak yorumlamaktadırlar.

"Sigara basıyor çocuğuna, yaramazlık yapıyor ya da söz dinlemiyor, basıyor sigarayl. İstismarın son aşaması benim için, tüylerim ürperiyor" (Ö12)

\section{Okul öncesi öğretmenlerinin duygusal istismara yönelik algıları}

Araştırmanın ikinci sorusu, okul öncesi öğretmenlerinin duygusal istismara yönelik algılarının ne olduğu yönündedir. Araştırma bulguları, örneklemdeki okul öncesi öğretmenlerinin duygusal istismar algılarının sözel saldırı ve davranışsal saldırı olmak üzere iki kategoriden meydana geldiğini göstermektedir.

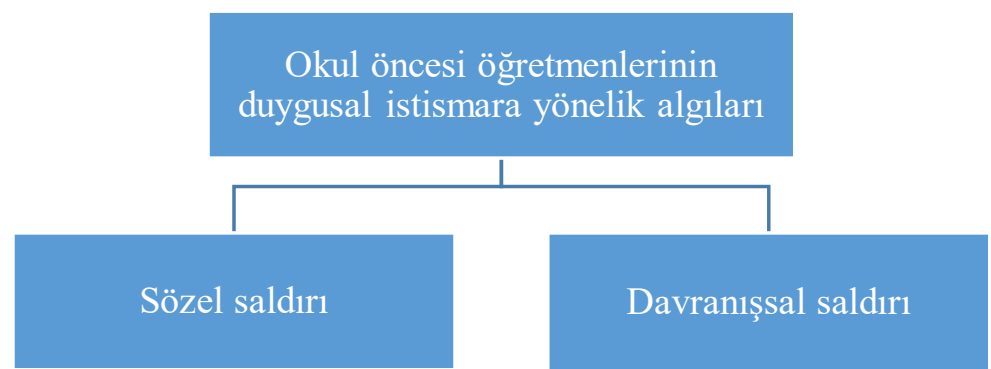

Şekil 2. Okul öncesi öğretmenlerinin duygusal istismara yönelik algıları

\section{Okul öncesi öğretmenlerinin sözel saldırıya yönelik algıları}

Okul öncesi öğretmenlerinin duygusal istismara ilişkin algılarından ilki, çocuğun benlik saygısına yönelik yapılan ve ciddi zararlara sebep olacağına inanılan sözel saldırıya ilişkindir. Öğretmenlerin sözel saldırıya yönelik algıları ise, doğrudan sözel saldırı ve dolayl yoldan sözel saldırl olmak üzere iki alt kategoriden meydana gelmektedir. 


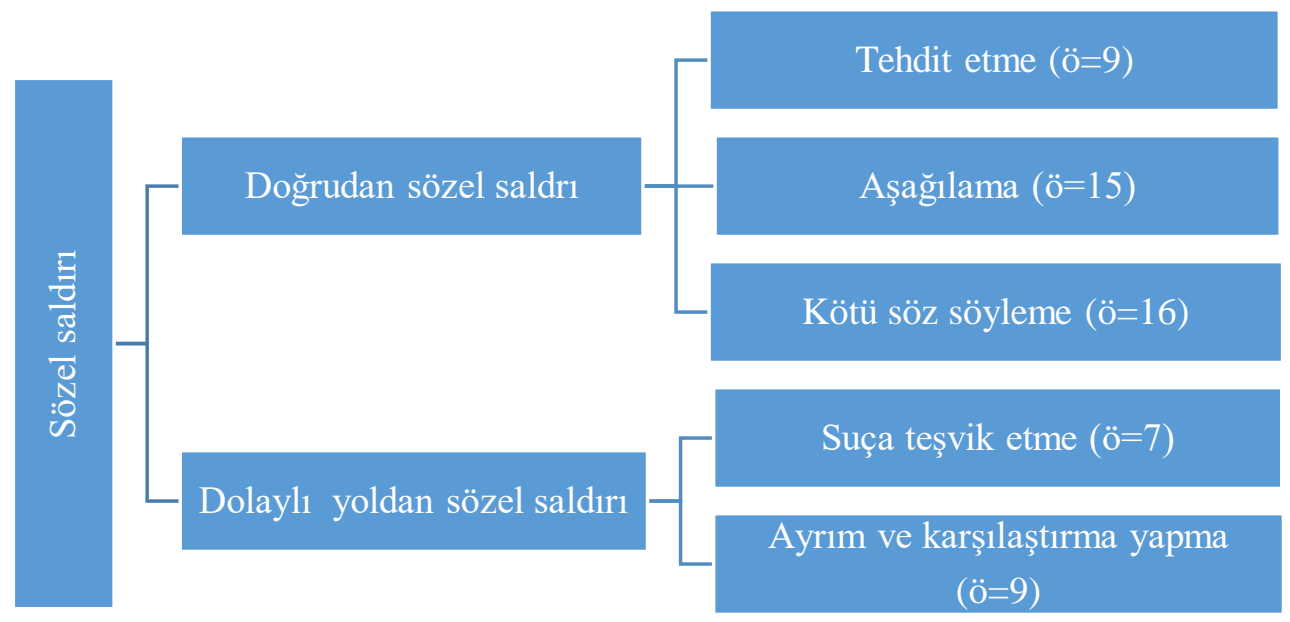

Şekil 3. Okul öncesi öğretmenlerinin sözel saldırıya yönelik algıları (ö: ilgili cevabı veren öğretmen sayısı)

Doğrudan sözel saldırı

Okul öncesi öğretmenleri, çocuğun kişiliğine zarar verici, benlik ve güven duygusunun gelişimine engel olacak şekilde direkt olarak birey ya da bireylerin çocuğa yönelttiği olumsuz söylemlerin istismar olduğunu dile getirmişlerdir. Katılımcılar, çocukların tehdit edilmeye, aşağılanmaya ve kötü sözlere birebir maruz kaldıklarını ve bu nedenle de, bu davranışların duygusal örselenmeye neden olan davranışlar olduğunu belirtmektedirler. Toplumsal olarak çok sık rastlanan bu davranışların toplumun büyük bir kesimi tarafından önemsiz olarak görülmesi ve rahatlıkla çocuğa yönelik yapılması öğretmenlerin rahatsız olduğu diğer bir durum olarak orta çıkmaktadır.

Tehdit etme davranışına ilişkin olarak okul öncesi öğretmenleri, çocuğun çevresindeki birey ya da bireylerin gerek isteklerini yerine getirmek gerekse de cezalandırmak amacıyla çeşitli söylemlerle tehditlerde bulunmalarını istismar davranışı olarak değerlendirdiklerini ifade etmektedirler.

“Çocuğun gururunu incitecek, rencide edecek, onu dinlemeden önyargılı bir şekilde tehdit cümleleri kullanarak korkutmak, duygusal açıdan yıpratıcı bir durumdur ve bunu maalesef okulda ögretmenler, evde ebeveynler çok sık kullaniyorlar" (Ö2).

"Bir tane velim, sürekli olarak çocuğunu 'evde öğretmenini ararım, ögretmenine söylerim' şeklinde tehdit ederek her istediğini yaptırıyormuş. Çocuk okula geldiğinde bana karşı uzak ve mesafeli davrantyordu, yani ürküyordu benden. Duyar duymaz hemen müdahale ettim" (Ö6).

Aşağılama davranışı ile ilgili olarak öğretmenler, çocuğun küçük düşmesine sebep olacak, gururunu zedeleyecek aşağılayıcı söylemlerde bulunmanın çocukta yetersizlik algısı yaratarak kişiliğine zarar vereceğini belirtmektedirler. Ayrıca öğretmenler, çocuğa lakap takma, dalga geçme, utandırma şeklinde davranışlarının çocuğun kendine güvensiz bir birey olarak yetişmesine yol açacağını ifade etmektedirler.

“Arkadaşlarının içerisinde onu küçük düşürecek aşağılayıcı sözler söylemek, onun duygusal olarak kötü hissetmesine neden olur. Çocuk güvenini kaybeder ve bu durum kişiliğini de olumsuz bir şekilde etkiler" (Ö9).

"Mesela çocuğu aşăğlayarak sürekli 'sen zaten beceriksizsin, başarısızsın, tembelsin' demek ya da dalga geçmek, alay etmek, bunların hepsi özgüven duygusunu zedeler ve duygusal istismardir" (Ö11). 
Kötü söz söyleme davranışı ile ilgili olarak ise okul öncesi öğretmenleri, çocuğun yakınındaki birey ya da bireylerin çocuğa direkt olarak kötü ve olumsuz sıfatlar (aptal, salak, geri zekâlı vb) kullanarak çağırmasının, küfür etmesi şeklindeki davranışları kapsayan söylemlerin, çocuğun duygularını olumsuz şekilde etkilediğini belirtmektedirler. Toplumsal olarak bu tür sözlerin basit ve sıradan algılanmasından ve kolay kullanılabilirliğinden duydukları rahatsızlı̆̆ dile getiren öğretmenler, bu tür davranışların birer istismar davranışları olduğunu ifade etmektedirler.

"Kullandiğın kötü bir sıfat ya da ses tonundaki vurguda aşağılama varsa, söylediğin kötü her şey onların duygularını etkileyecektir. Duygusal anlamda etkileyecek şekilde ise tabii ki bu bir istismardır" (Ö21).

"Özellikle çocukların ebeveynleri ve ögretmenleri tarafindan küfre; aptal, salak, geri zekâlı gibi laflara maruz kaldıklarını çok sık duyuyoruz. Özellikle yolda, herkesin içinde annelerin sürekli bu tür sifatlar kullanmasina sinir oluyorum. Toplum tarafindan basit görünüyor ama bu tür sözler tabiî ki duygusal istismardır” (Ö26).

Dolaylı yoldan sözel saldırı

Öğretmenlerin sözel saldırılara ilişkin ortaya koydukları ikinci kategori, dolaylı yoldan sözel saldırıdır. Öğretmenler, çocuğun yakınındaki birey ya da bireylerin çocuğa karşı yanlış tutumları ve yönlendirmeleri sonucu olumsuz davranışa teşvik etmelerini ve akranları ya da başka kişilerle karşılaştırmaya yönelik ayrım ve kıyaslama içeren söylemlerde bulunmalarını birer duygusal istismar davranışı olarak görmektedirler.

Olumsuz davranışa teşvik etmeyi öğretmenler, ebeveynlerin ya da çocuğun bakımından sorumlu diğer kişilerin çocuğun kendi gelişimine zarar verecek davranışlarda bulunmasına seyirci kalmaları, cesaretlendirilmeleri, teşvik etmeleri, hoş görmeleri ya da görmezden gelmeleri olarak ifade etmektedirler. Öğretmenler, çeşitli gerekçelerle çocuğun yakınları tarafından sergilenen bu tür davranışları, çocuğun ahlaki yapısını bozması ve sağlıklı davranışlar geliştirmesine zarar vermesinden dolay1, istismar olarak kabul ettiklerini belirtmektedirler.

"Nasıl aşırı otoriter aile tutumu çocuk için zarar verici ise, aşırı hoşgörülü tutum da zarar vericidir. Çocuk saatlerce bilgisayar başında kallyor. 'biz görmedik, çocuğumuz görsün' mantı̆̆lyla çocuğun sinırsı özgürlüğ̈̈ var. Ne izliyor?, neler ögreniyor?, iyi mi öğreniyor? kötü mü ögreniyor? Aileler farkında değil" (Ö12).

“Ailelerin büyük çoğunluğunda 'kendini savun', 'sana vururlarsa sende vur' şeklinde konuşmaları sinıf ortamında çok duyuyorum. Evet, çocuk kendini savunmalı ama bu konuşmaların çok fazla cesaretlendirildiği çocuklarda inanılmaz şiddet ve saldırgan davranıșlar söz konusu. Ailenin bilinçsizce çocuğu șiddete teșvik etmesi istismardır" (Ö5).

Ayrım ve klyaslama yapma davranışı ile ilgili olarak ise öğretmenler, çocukların çevresindeki birey ya da bireylerin gerek sosyo-ekonomik durumlarından dolayı gerekse de herhangi bir konuda çocuğun çabasının artacağına inandıklarından dolayı ayrım ve kıyaslamalarda bulunduklarını belirtmektedirler. Özellikle evde anne babaların, okulda ise öğretmenlerin kıyaslama ve ayrım davranışlarını çok sık kullandıkları görüşünde olan öğretmenler, bu davranışları çocuğu duygusal olarak yıpratan ve istismara neden olan davranışlar olarak değerlendirmektedirler.

"Mesela velilerin en çok yaptı̆̆ı şey çocuklarını diğer çocuklarla kıyaslayarak baskı yapmalarıdır (Ö5)”. 
"Okulumuza her yerden her kesimden öğrenci gelebiliyor. Mesela apartman görevlisi çocuğu da, doktor çocuğu da gelebiliyor. Çocuğu diğerlerinden olumsuz şekilde ayırt ettirecek hareketler; sen yaptın sen yapamadın şeklinde kiyaslamalar duygusal istismardır. Sinıf içerisinde belirli çocuklara güzel davranıp, bazı çocukları etiketlemek de istismardır" (Ö9).

\section{Okul öncesi öğretmenlerinin davranışsal saldırıya yönelik algıları}

Okul öncesi öğretmenlerinin duygusal istismara yönelik algılarına ilişkin ikinci kategoriyi, çocuğun duygusal ve sosyal gelişimine zarar verici olduğuna inandıkları davranışsal saldırılar oluşturmaktadır. Çocuğa çevresindeki birey ya da bireyler (ebeveyn, öğretmen, bakıcı vb) tarafından yapılan, çocuğun duygusal iletişim bağı kurmasını engelleyici ya da baskılayıcı tutumların söz konusu olduğu davranışsal saldırılara ilişkin doğrudan ve dolaylı yoldan davranışsal saldırı olmak üzere iki alt kategori ortaya çıkmaktadır.

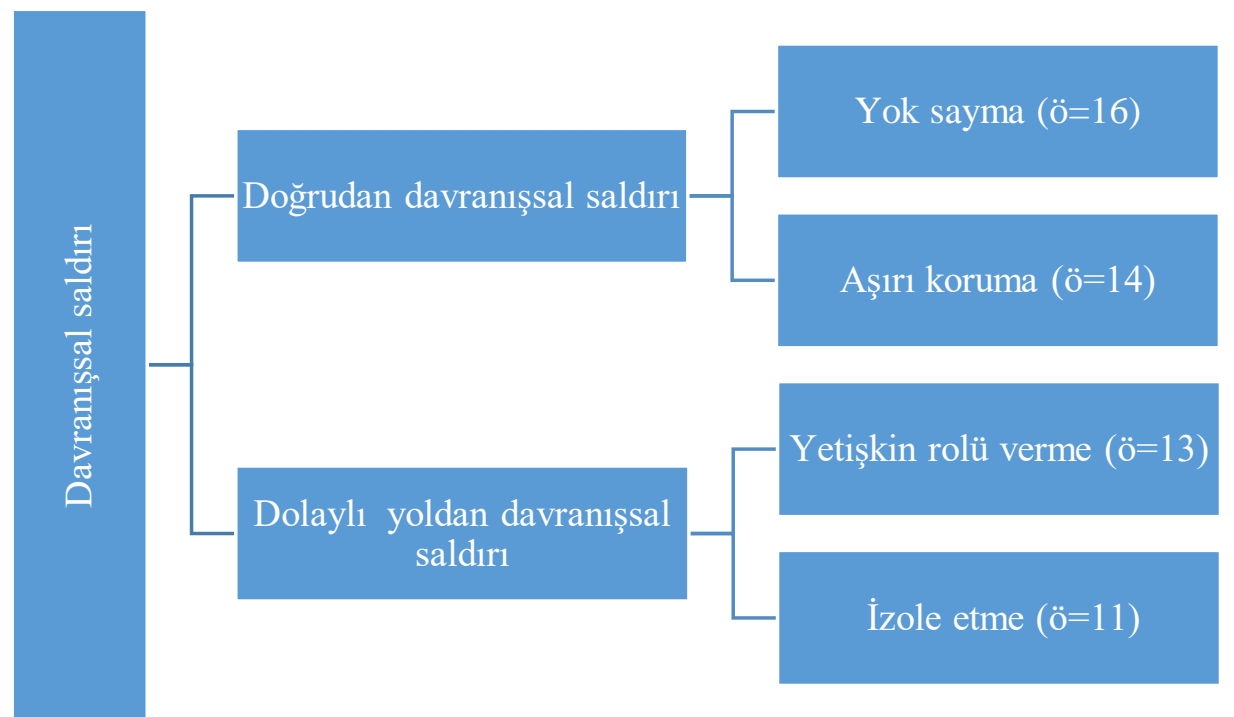

Şekil 4. Okul öncesi öğretmenlerinin davranışsal saldırıya yönelik algıları

(ö: ilgili cevabı veren öğretmen sayısı)

\section{Doğrudan davranışsal saldırı}

Öğretmenlerin davranıșsal saldırıya ilișkin ortaya koydukları ilk alt kategori, doğrudan davranışsal saldırıdır. Doğrudan davranışsal saldırıya ilişkin öğretmenler, çocuğun çevresindeki birey ya da bireyler tarafından direkt olarak gerçekleştirilen ve duygusal iletişim becerilerinin gelişimine, karar verme ve irade gücüne zarar veren davranışları işaret etmektedirler. $\mathrm{Bu}$ davranışlar, çocuğu yok sayma ve aşırı koruma davranışları olarak ifade edilmiştir.

Yok sayma davranışı ile ilgili olarak okul öncesi öğretmenleri, çevresindeki bireyler tarafından kasıtlı ya kasıtsız olarak çocuğun duygularına karşılık verilmemesini ve yeterli duygusal doyumun çocuğa yaşatılmamasını duygusal olarak zarar verilen bir davranış olarak değerlendirmektedirler.

"Çocuğu bilerek görmezlikten gelmek, sorularını yok saymak, tabiî ki duygusal anlamda çocuğu zedeler. Gerçekten bir öğretmen ya da anne bilerek çocuğun söylediklerini dinlemeyip bir şekilde cevap vermiyorsa, bu duygusal istismardır” (Ö4).

Aşırı koruma davranışı ile ilgili olarak öğretmenler, çocuktan sorumlu kişilerin, dışarıdan çok ilgili ve çocuğun bütün ihtiyaçlarını karşılayan bireyler olarak görünmelerine karşın, çocuğun davranış ve karar verme yetisini baskılayıcı ve kısıtlayıcı şekilde aşırı üzerine 
düşme ve kollama davranışlarını, çocuğun kendi ayakları üzerinde duran ve kendine yeten birey olarak yetişmesine engel olan davranışlar olarak görmekte ve bu davranış biçimini istismar olarak yorumlamaktadırlar.

"Aşırı kollayıcı velilerin çocukları da aşırı güvensiz oluyor ve yetersiz kendi başlarına hiçbir şey yapamayan bireyler oluyorlar, bunun sonucunda bu aşırı koruyucu ailelerde çocuklarına hem duygusal anlamda hem de psikolojik anlamda baskı yaparak farkinda olarak ya da olmayarak istismar etmiş oluyorlar. Çünkü bizim eğitim sürecimizin sonucunda bireyin kendine yeterli olmasinı sağlamak geliyor" (Ö3).

\section{Dolaylı yoldan davranışsal saldırı}

Okul öncesi öğretmenlerinin davranışsal saldırıyla ilgili algılarına ilişkin ikinci alt kategori, dolaylı yoldan davranışsal saldırıdır. Öğretmenlerce dolaylı yoldan davranışsal saldırı, çocuğun çevresindeki birey ya da bireylerce, çocuğun kapasitesinin ve yeterliliğinin üzerinde beklentiler içine girilerek çocuğa yetişkin rolü verilmesi ve çocuğun akranları veya toplumdaki diğer bireyler ile iletişim kurmasının engellenmesi sonucunda sosyal ve duygusal olarak izole edilmesi şeklinde yorumlanmaktadır.

Yetişkin rolü verme davranışını okul öncesi öğretmenleri, çocuğun kapasitesinin ötesinde, kaldıramayacağı sorumlulukların verilmesini, çocukla ilgili yapabileceğinden fazla davranışsal ya da akademik beklentilere girilmesini ve buna ilişkin çocuğa baskı yapılmasını istismar davranışı olarak değerlendirmektedirler.

"Özellikle bazı kuralcı ailelerde görüyorum ben, çocuğun çocuk olduğunu unutup yetişkin gibi davranmasını bekliyorlar. Oturmasına, kalkmasına, davranışlarına, her şeyine müdahale eden, eleştiren, hemen çocuğu gözünde yetişkin rolüne büründüren anne babalar var. Bu çocuğu yorar, özellikle sürekli eleştiri almak, baskı altında olmak yıpratan bir şeydir" (Ö5).

İzole etme davranışını ise okul öncesi öğretmenleri, çocuğun bir toplum ya da ortam içerisinde eksik yönlerinin vurgulanarak dışlanması, yalnız bırakılması, ceza yöntemi olarak çocuğun odaya ya da banyoya kapatılması, akranlarıyla olan etkinliklere katılmasına izin verilmemesi veya katılmasına yönelik ortamın sağlanmaması olarak ifade etmekte, bu durumda çocuğun kendini yalnız, değersiz ve dışlanmış hissedebileceğini düşünmekte ve bu tür davranışları duygusal istismar olarak değerlendirmektedirler.

"Mesela öğretmenin çocuğun eksik yönlerini sinıf içerisinde yüzüne vurarak söylemesinin, 'senin annen baban ayrı olduğu için' tarzı cümlelerle çocuğun eksik yönlerini deşifre etmesinin ve çocuğu ötekileştirmesinin, benim için duygusal etkileri vardır" (Ö4).

Okul öncesi öğretmenleri, kendilerinin çocuklara yönelik asla fiziksel istismarda bulunmadıklarını fakat sınıf içerisinde düzeni sağlamak adına bir takım sınıf yönetimi yöntemlerini kullandıklarını ifade etmişlerdir. Öte yandan, öğretmen ifadelerinde bu yöntemlerin literatürde duygusal istismar olarak nitelendirilen düşünme sandalyesine oturtma (izole etme) ve sevdiği şeyden mahrum bırakma davranışları olduğu görülmektedir.

Düsünme sandalyesine oturtma ile ilgili olarak katılımcılar, çocuklar yaramazlık yaptıklarında, sınıfın düzenini bozduklarında ya da kurallara riayet etmediklerinde, kesinlikle herhangi zarar verici fiziksel temasta bulunmadıklarını, fiziksel istismardan kaçınmak için bunun yerine çocuğu düşünme sandalyesine ya da köşesine göndererek oturttuklarını ifade etmişlerdir. Hatta bunun zor durumda kaldıklarında yapmak zorunda oldukları bir yönetim biçimi olduğunu dile getirmişlerdir. 
"Ben sinıf içerisinde yaramazlık yapan çocukları düşünme köşesine koyarım. 'Otur, ne yaptığını düşün' derim. Bunun ötesinde çocuklara fiziksel olarak zarar verecek davranışlarda bulunmam" (Ö16).

"Onlara fiziksel şiddette bulunmuyorum asla. Bunun yerine sinıf içerisinde çok yaramaz bir çocuk varsa sandalyede bekletirim. En etkili yöntem bu” (Ö23).

Sevdiği şeyden mahrum bırakma ile ilgili olarak ise öğretmenler, sınıf içerisinde fiziksel istismarda bulunmadıklarını, fakat çocukların sınıf kurallarına uymadıkları ya da düzeni bozdukları durumlarda onları sevdikleri şeylerden mahrum bırakarak düzen sağlamaya çalıştıklarını belirtmişlerdir.

"Mesela yaramaz bir öğrencim var. Yumuşak davrandım, bu sefer tepeme çıkmaya başladl. O da olmadl. Orta yolu nasıl buldum? Onu sevdiği şeylerden mahrum etmeye başladım. Hamurla oynamayı çok seviyordu. Diyordum ki bugün arkadaşına bunu yaptığın için hamurla oynamayacaksın" (Ö5).

\section{Okul öncesi öğretmenlerinin cinsel istismara yönelik algıları}

Okul öncesi öğretmenlerinin cinsel istismara yönelik algıları, temas içeren ve temas içermeyen cinsel saldırı olmak üzere iki alt kategoriden oluşmaktadır.

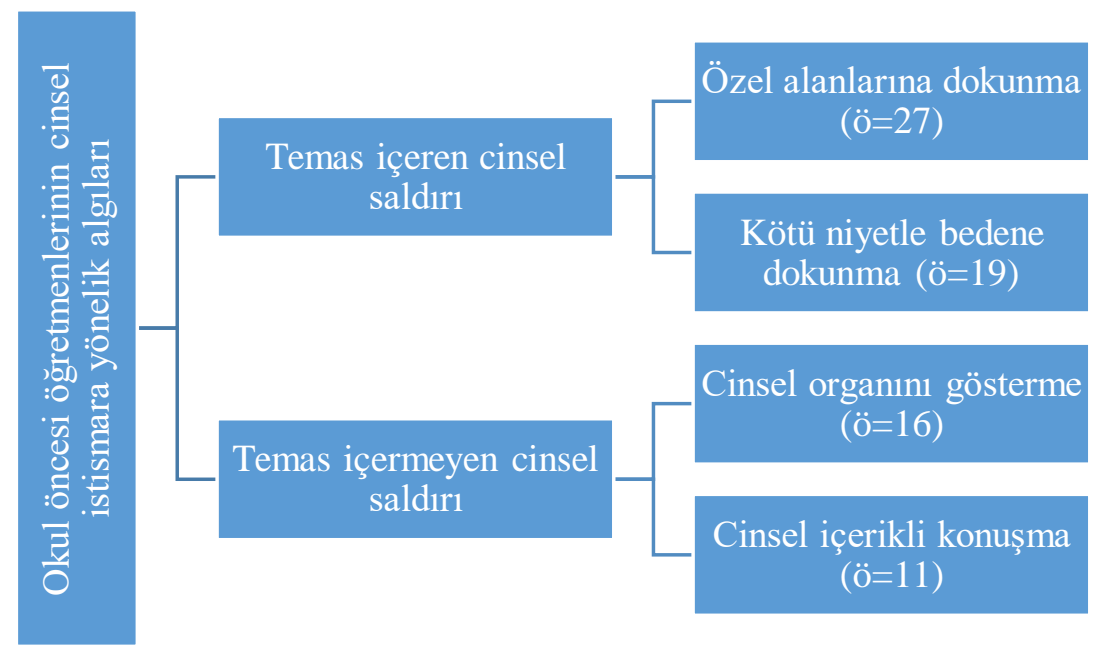

Şekil 5. Okul öncesi öğretmenlerinin cinsel istismara yönelik algıları (ö: ilgili cevabı veren öğretmen sayısı)

\section{Temas içeren cinsel saldırı}

Okul öncesi öğretmenlerinin cinsel saldırıya ilişkin algılarına dair birinci alt kategori, temas içeren cinsel saldırıdır. Öğretmenler, temas içeren cinsel davranışlar olarak, çocuktan büyük bir yetişkin tarafindan çocuğun bedeninin herhangi bir bölümüne ve/veya özel bölgelerine cinsel haz almak amacıyla temasta bulunulmasını ifade etmişlerdir. $\mathrm{Bu}$ tür istismar davranışları ise öğretmenler tarafından iki şekilde açıklanmıştır. Bunlar, çocuğun özel alanlarına dokunma ve kötü niyetle bedenin diğer alanlarına dokunma şeklindedir.

\section{Özel alanlarina dokunma}

Özel alanlarına dokunma davranışını, çocuğun cinsel organlarına kendinden yetişkin birey ya da bireyler tarafından cinsel tatmin amaçlı temasta bulunulması olarak ifade eden ögretmenler, cinsel istismar ile ilgili ilk olarak çocuğun özel alanlarına yönelik zarar verme davranışlarına ilişkin ifadelerde bulunmuşlardır. Cinsel istismar olgusunu öğretmenlerin, sadece çocuğun cinsel 
alanlarına yönelik yapılan taciz, tecavüz ve cinsel alanlara dokunma olarak düşündükleri ve ifade ettikleri görülmektedir.

"Bana göre öncelikle büyük birinin çocuğa vücudunun belli bölümlerine dokunması cinsel istismar olduğunu düşündürür. Özel bölgesine dokunması, özel yerlerine dokunması, öpmeye çalışması istismardır” (Ö4).

"Birileri bir çocuğun özel bölgelerine dokunmuş ve zarar verecek hareketlerde bulunmuşsa cinsel istismar olduğunu düşünürüm. Örneğin taciz, tecavüz olayları gibi (Ö6)".

Kötü niyetle bedenin diğer alanlarına dokunma

Öğretmenler, kendinden büyük bir yetişkin tarafından çocuğun özel alanları dışında, bedeninin herhangi bir yerine (kol, bacak, yüz vs) cinsel tatmin sağlamak amaciyla kötü niyetle dokunulmasının da cinsel istismar olduğunu ifade etmişlerdir.

"Ĕger çocuğu normal tutmanın dışında, kötü niyetle cinsel haz almak amacıyla okşaya okşaya kolundan tutmuşsan cinsel istismardır" (Ö7).

"Karşıdaki kişi çocuğa farkll yaklaşarak kendini tatmin etmeye yönelik, koluna yüzüne, eğer cinsel tatmin amaçlı dokunuyorsa istismar etmiş olur" (Ö8).

Bazı okul öncesi öğretmenleri de, cinsel istismara yönelik olan cinsel amaçlı fiziksel temasta bulunma davranışını fiziksel istismar olarak dile getirmişlerdir. Öğretmenler, çocuğa kötü hissettirecek dokunmaların, kötü niyetle yapılan fiziksel temasların ve bedenin özel bölgelerine dokunulması şeklinde yapılan fiziksel temasların kendilerine fiziksel istismarı düşündüren davranışlar olduğunu ifade etmişlerdir. Bu durumda, cinsel istismar davranışını fiziksel istismar olarak değerlendirmiş ve buna yönelik ifadelerde bulunmuşlardır.

“Çocuğa kötü hissettirecek şekilde dokunmakya da bir temasta bulunduğunda mesela bir anne, baba, ögretmen sevgisi değil de farkl ş̧ekilde cinsel amaçl dü̈şümeye sevk edecek bir temasta bulunulduğunda, ben fiziksel istismar olduğunu düşünürüm” (Ö9).

"Vücudunun herhangi bir yerine yapılan bir dokunma ama nasll yapılan bir dokunma, kötü yapılan bir dokunma, kötü niyetle yapılan cinsel bir dokunma benim için fiziksel istismardır. Son zamanlarda hep televizyonlarda çocuklara taciz duyuyoruz" (Ö31).

\section{Temas içermeyen cinsel saldırı}

Okul öncesi öğretmenlerinin cinsel istismara ilişkin algılarına dair ikinci alt kategori, temas içermeyen cinsel saldırıdır. Bazı öğretmenler, kendilerine cinsel istismarı düşündüren davranışların temas içermeyen cinsel davranışlar olduğunu ifade etmişlerdir. Cinsel istismar olması için sadece temas gerektiren cinsel içerikli davranışların olmasının gerekmediğini, çocuktan büyük bir yetişkin tarafından çocuğa yönelik yapılan ve dokunma içermeyen fakat cinsel içeriğe sahip davranışların cinsel istismar olduğunu belirtmişlerdir. Temasın yer almadığ 1 cinsel içerikli davranışlar, cinsel organını gösterme ve cinsel içerikli konuşmalar olmak üzere iki şekilde ifade edilmiştir.

\section{Cinsel organını gösterme}

Cinsel organını gösterme, öğretmenlere cinsel istismarı düşündüren davranışlar arasında yer alan ve temas bulunmamasına rağmen çocuğa psikolojik olarak ciddi zarar veren davranışlardan biridir. Cinsel istismar, temasta bulunmadan cinsel içerikli davranışların çocuğa yönelik gösterilmesi durumlarını da içermektedir. Öğretmenler, çocuğun kendinden büyük bir birey 
tarafından cinsel organını gösterme davranışına maruz kalmasını, cinsel istismar olarak dile getirmişlerdir.

"Küçük bir çocuğa cinsel içerikli şekilde hareketler yapmak, mesela yetişkin birinin cinsel organını göstermesi, bunlar benim için cinsel istismardır” (Ö4).

"Bir yetişkin ya da kendinden büyük bir çocuk da olabilir mesela, çocuğa kendisi herhangi bir özel yerini gösteriyorsa ki bunu duyuyoruz, o çocukta yarattı̆̆ travmayı düşünemiyorum. Cinsel istismardır, burada çocuğa dokunmadı ama çocuğun psikolojisini mahvetti” (Ö11).

Cinsel içerikli konuşmalarda bulunma

Cinsel içerikli konuşmalarda bulunma davranışı, cinsel temas olmamasına karşın çocuğun bilinçaltında anlamlandıramayacağı travmatik durumlara sebep olduğundan dolayı öğretmenler tarafından cinsel istismar olarak değerlendirilmektedir. Öğretmenler, sadece cinsel temas içeren davranışların değil temas olmadan yapılan cinsel içerikli hareket ve konuşmaların da istismar olduğunu ifade etmektedirler.

"Bazı hasta insanlar dokunmaz ama cinsel içerikli konuşmalarda bulunur çocuğa. Bilinçaltını mahveder. Bu da bir cinsel istismardır tabii ki. Sadece cinsel temasta bulunmak anlamina gelmiyor istismar" (Ö6).

\section{Okul öncesi öğretmenlerinin fiziksel ihmale yönelik algıları}

Araştırma sorularından dördüncüsü, okul öncesi öğretmenlerinin fiziksel ihmali nasıl algıladıkları yönündedir. Araştırma bulgularına göre, okul öncesi öğretmenlerinin fiziksel ihmali temel gereksinimlerin yetersiz karşılanması ve fiziksel koşulların yetersizliği olmak üzere iki şekilde algıladıkları görülmektedir.

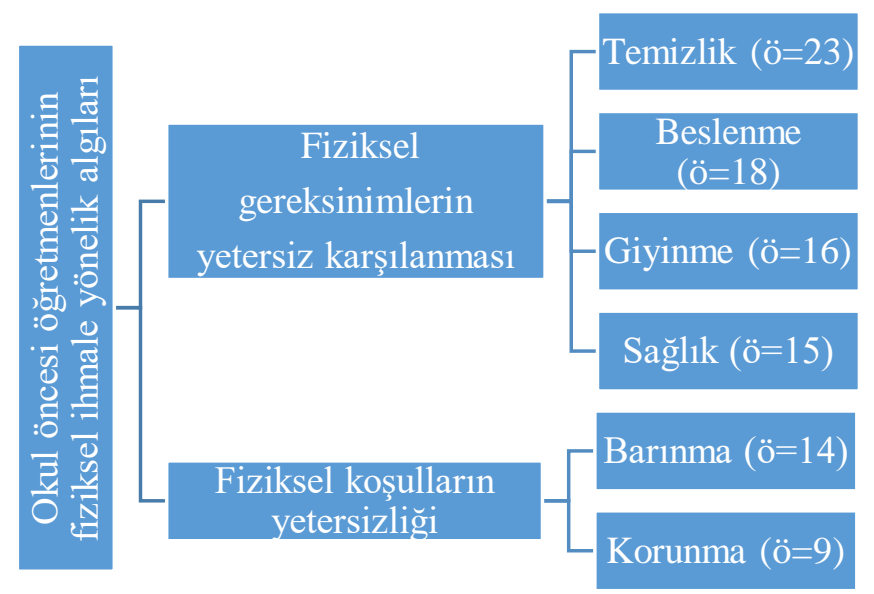

Şekil 6. Okul öncesi öğretmenlerinin fiziksel ihmale yönelik algıları

(ö: ilgili cevabı veren öğretmen sayısı)

\section{Fiziksel gereksinimlerin yetersiz karşılanması}

Okul öncesi öğretmenlerinin fiziksel ihmale ilişkin algılarına dair birinci alt kategori, çocuğun fiziksel gereksinimlerinin yetersiz karşılanmasıdır. Öğretmenler fiziksel ihmali, çocuğun temel gereksinimlerini karşılamada yoksunluk ya da yetersizlik içeren davranışlar olarak ifade etmişlerdir. Öğretmenlere göre, çocuğun temel fiziksel ihtiyaçlarının kasıtlı ya da kasıtsız şekilde karşılanmaması ve gelişim alanlarını tehdit edecek duruma gelmesi fiziksel ihmaldir. Çocuğun gelişim sürecinde ihmal edilen temel ihtiyaçlarını ise öğretmenler temizlik, beslenme, giyinme ve sağllk olarak dile getirmektedirler. 
Temizlik

Temizlik, karşılanmaması durumunda öğretmenlere fiziksel ihmali düşündüren temel ihtiyaçlardan birincisidir. Çocuğun özbakımı ve gelişimi açısından bedeninin temel ihtiyaçlarından olan temizliğin yeterli düzeyde ve zamanında yerine getirilmemesi çocuğun fiziksel olarak ihmal göstergeleri arasında görülmektedir. Çocuğun özbakım ihtiyaçlarının kendinin bakımından sorumlu kişi ya da kişiler tarafından yeterince yapılmaması ya da çocuğun bu konuda yönlendirilmemesi katılımcıların sık şekilde rastladığ 1 ve ihmal olarak değerlendirdiği davranışlardan biridir.

"Çocuğun tırnakları uzamış, kir içinde, uzun zaman banyo yaptırllmıyor. Burada çocuğun temizliği ihmal edilmiş oluyor. Çocuğun özbakımına yönelik yapılmayan her şey fiziksel ihmal olur benim için” (Ö2).

"Çocuk sürekli yataktan uyandiğı gibi. Elini yüzünü yıkamadan, daha doğrusu temizlik ihtiyaçların gidermeden okula geliyor. Bu da bana çocuğun fiziksel ihmalini gösteriyor" (Ö4).

\section{Beslenme}

Beslenme, çocuğun sağlıklı ve yeterli şekilde besin ihtiyacının karşılanmaması durumunda öğretmenlere ihmali düşündüren temel ihtiyaçlardan bir diğeridir. Özellikle çocuğun bakımdan sorumlu kişilerin, çocuğu hazır yiyeceklerle beslemesini ve öğün olarak kullanmasını ihmal olarak nitelendiren öğretmenler, bu durumla sık karşılaştıklarını ve bunu yanlış bir tutum olarak gördüklerini ifade etmişlerdir.

"Öğrencim beslenmesi olmadan okula geliyor. Arlyorum, anne koymayı unuttum diyor ama bu sürekli oluyor. İhmalkârlık yapıyor çocuğuna" (Ö2).

"En çok beslenme konusunda ihmal oluyor bence. Annenin evde imkânları doğrultusunda kek yapabilecek durumu varken sürekli çocuğuna hazır gıdalar koyuyor, sağılığını ihmal ediyor" (Ö3).

\section{Giyinme}

Giyinme, çocuğun temel ihtiyaçlarından biri olan ve eksik ya da yanlış şekilde yapılması durumunda öğretmenlere ihmali düşündüren bir diğer temel ihtiyaçtır. Çocuğa ihtiyacına yönelik yeterli kıyafetin sağlanmaması, çocuğun mevsimine uygun şekilde giydirilmemesi ve kıyafetine gerekli özenin gösterilmemesi, öğretmenlerin karşılaştıkları ve ihmal olarak nitelendirdiği bazı davranışlardır.

"Yaz Günü klşlık klyafet giydiriliyor veya tam tersi klşın yazlık kıyafetle geliyor, üşütüyor çocuk. Bunların hepsi meslek hayatımız boyunca karşılaştığımız şeyler” (Ö3).

"Bir ögrencim vardl, aynı klyafetle ertesi gün yine gelirdi. Üstüne bir şey döküldüyse o leke üstünde kalmış şekilde okula gelirdi. Bu da bir ihmaldir” (Ö5).

Săgllk

Sağl1k ile ilgili olarak öğretmenler, çocuğun bedeninin her hangi bir bölümünde gelişimini ve büyümesi aksatan rahatsızlıkların meydana gelmesi ve çocuğun bakımından sorumlu kişi ya da kişilerin kasıtlı ya da kasıtsız olarak gerekli ilgi ve ihtiyaçlarını karşılamaması durumunda ihmalin söz konusu olduğunu ifade etmişlerdir. Çocukta çeşitli sebeplerle meydana gelen sağlık problemlerinin farkına varmama, geç müdahalede bulunma ya da bulunmama ve sağlık sorununu önemsememe gibi durumlarla karşılaştıklarını ifade eden öğretmenler, bunun fiziksel bir ihmal olduğunu dile getirmişlerdir. 
"Bir öğrencim var çok hareketli. Bu çocuk ateşli de olsa annesi onun ilaçlarını çantasına koyarak okula gönderir. Çocuk kötü olur yine de gönderir. Çünkü çocuğun okulda kalması anne için de bir dinlenme süresidir. Bu durumda anne ne yapmış oluyor? Çocuğun să̆lığını ihmal etmiş oluyor" (Ö2).

"En çok dikkatimi çeken ihmal şekli, çocuk hasta olmuş ateşler içinde yanıyor. Anne ev hanımı, çocuğu o şekilde okula gönderiyor. Öğretmen tekrar anneyi arıyor. Çocuğun hasta olduğunu söylüyor. Anne tekrar gelip çocuğu altyor" (Ö4).

\section{Fiziksel koşulların yetersizliği}

Okul öncesi öğretmenlerinin fiziksel ihmale ilişkin algılarına dair ikinci alt kategori, fiziksel koşulların yetersizliğidir. Öğretmenler, çocuğun fiziksel koşullarının çeşitli sebeplerle yeterli şekilde sağlanmamasıyla ortaya çıkan durumu, fiziksel ihmal olarak algılamakta ve yorumlamaktadırlar. Eğitimciler fiziksel koşulların yetersizliğine ilişkin olarak barınma ve güvenliğe ilişkin yetersizlikleri dile getirmişlerdir.

\section{Barinma}

Barınma ile ilgili olarak okul öncesi öğretmenleri, çocuğun yaşadığı mekânın temizliğinin, ısınmasının, kullanım koşullarının sağlıklı ve yeterli şekilde sağlanamamasını ve çocuğun bu koşullar içerisinde yaşamak zorunda bırakılmasını fiziksel ihmal olarak algılamakta ve yorumlamaktadır.

"Bir öğrencime ev ziyaretinde bulundum yakın zamanda. Evde iki oda var, mutfak yok, sadece ara bir yerde anne hortumla yerde eğilerek bulaşık yıkıyor. Ev rutubetli ve kirli. Çocuğun o şartlarda büyümesi gerçekten çok zor bir durum” (Ö16).

\section{Güvenlik}

Okul öncesi öğretmenleri, çocuğun bakımından sorumlu birey ya da bireyler tarafından çocuğun korunma ve güvenliğine ilişkin gerekli önlemlerin alınmamasını, dikkatli davranılmamasını ve çocuk için tehlike oluşturacak durumların olmasını, fiziksel ihmal olarak algılamakta ve yorumlamaktadırlar.

"Bir ara televizyonlarda çok rastlyyorduk. Hani çocuk pencereden sarklyor, birileri fark ediyor ve çocuk kendini atınca ya birileri tutuyor ya da itfaiye yetişiyor. Bu annenin bir ihmali işte. Böyle bir şeye sebebiyet vermemesi dikkat etmesi gerekir” (Ö1).

\section{Okul öncesi öğretmenlerinin duygusal ihmale yönelik algıları}

Araştırma sorularından beşincisi, okul öncesi öğretmenlerinin çocuğa yönelik duygusal ihmali nasıl algıladıklarıdır. Araştırma bulguları öğretmenlerin duygusal ihmali, psikolojik ve ruhsal gereksinimler ile sosyal gereksinimlerin yetersiz karşılanması olmak üzere iki şekilde algıladıklarını göstermektedir. 


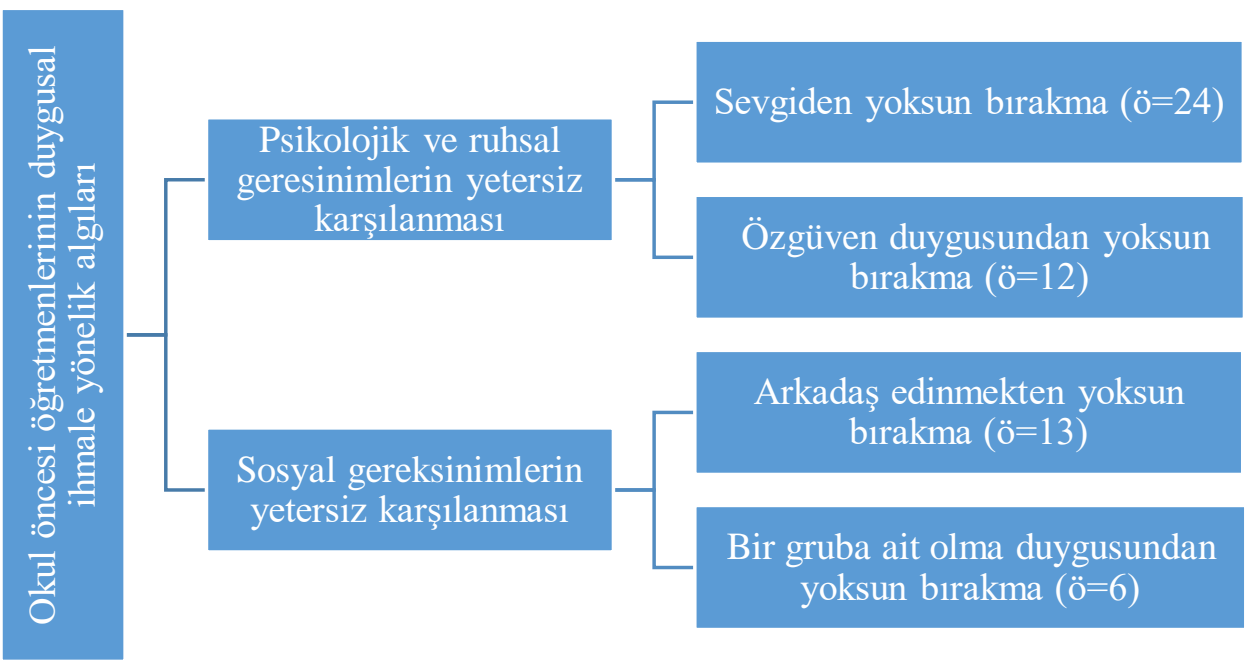

Şekil 7. Okul öncesi öğretmenlerinin duygusal ihmale yönelik algıları (ö: ilgili cevabı veren öğretmen sayısı)

\section{Psikolojik ve ruhsal gereksinimlerin yetersiz karşılanması}

Okul öncesi öğretmenlerinin duygusal ihmale ilişkin algılarına dair birinci alt kategori, psikolojik ve ruhsal gereksinimlerin yetersiz karşılanmasını içermektedir. Öğretmenler, kendilerine duygusal ihmali düşündüren davranışları, çocuğun psikolojik ve ruhsal gereksinimlerini karşılamada yoksunluk ya da yetersizlik içeren davranışlar olarak ifade etmişlerdir. Öğretmenler, psikolojik ve ruhsal gereksinimlerin yetersiz karşılanması olarak sevgiden yoksun bırakma ve özgüven duygusundan yoksun bırakma davranışlarını dile getirmişlerdir.

\section{Sevgiden yoksun birakma}

Çocukların ruhsal ve psikolojik açıdan en çok gereksinime ihtiyaç duydukları davranışın sevgi olduğunu dile getiren öğretmenler, ebeveynlerin ya da yakın çevredeki diğer kişilerin kasıtlı ya da kasıtsız olarak çocuğu sevgiden yoksun bırakmasını ihmal olarak nitelendirmektedirler.

"Tabii ki en önemlisi sevgidir. Ailelerin çocuğa sevgi vermesi en büyük ihtiyaçtır aslında. Anne, baba, ögretmen, yakın çevresi tarafindan sevildiğini bilmek o kadar önemli bir şey ki çocuk için. Bunları yerine getirmemek, çocuğa önemli olduğunu hissettirmemek, duygusal ihmaldir" (Ö1).

"Bir çocuğu seviyor olabilirsiniz, fakat sevginizi çocuğunuza ister bilerek ister bilmeyerek hissettiremiyorsaniz bu bir ihmaldir" (Ö6).

Özgüven duygusundan yoksun birakma

Öğretmenler, ailelerin çocuklarının üzerine fazla düşmelerinin ve onları bağımlı şekilde yetiştirmelerinin, çocukları özgüven duygusundan yoksun bıraktığını ve bunun da duygusal ihmal olduğunu belirtmektedirler.

"Bazı aileler de çocuğunun üstüne aşırı düşüyor. Ben bunu çok yanlı̧̧ buluyorum. Çocuğun kendi ayakları üzerinde durmasına ket vuruyorlar. Çocuk küçük yaştan itibaren birilerine bă̆ımlı bir şekilde yetiştirilmeye çalışılıyor. Bu da çocuğun özgüvenini kırıyor ve ileriki yaşlarında daha sıkıntılı bir birey olmaya başllyor. Çocuğun özgüvenini ve özsaygısın korumayı ihmal ediyorlar" (Ö7).

"Çocuğun aşırı üstüne düşen aileler de çocuklarına kaygı ve korku vermiş oluyor. Sen burada çocuğun özgüvenini elinden almış oluyorsun. Çocuk özerk olamiyor. Çok ince bir 
denge; aşırı ilgide çocuğa zarar veriyor, çocuğun kişiliğini ihmal etmiş oluyorsun”" (Ö10).

\section{Sosyal gereksinimlerin yetersiz karşılanması}

Okul öncesi öğretmenlerinin duygusal ihmal algılarına dair ikinci alt kategori, sosyal gereksinimlerin yetersiz karşılanmasını içermektedir. Öğretmenler, çocuğun temel ödev ve ihtiyaçlarından biri olan sosyalleşmesini engelleyici davranışların söz konusu olmasını, duygusal bir ihmal olarak ifade etmektedirler. Öğretmenlere göre, çocuğun sosyal gereksinimlerinin ihmali davranışları, çocuğu arkadaş edinmekten yoksun bırakma ve bir gruba ait olma duygusundan yoksun birakmadir.

Arkadaş edinmekten yoksun birakma

Çocuğun sosyal ve duygusal gelişiminin sağliklı şekilde meydana gelmesinde en önemli etkenlerden birinin arkadaşlık olduğunu ifade eden okul öncesi öğretmenleri, çocuğun çevresindeki birey ya da bireyler tarafından çocuğun akranlarıyla sağlıklı ilişkiler kurmasını engelleme ve önemsememe gibi davranışların söz konusu olmasını duygusal ihmal olarak yorumlamaktadirlar.

"Oryantasyon döneminde bazı çocuklar girişken, bazıları utangaç mesela. Ben hemen birbirleriyle kaynaşmaları, özellikle de çekingen çocukların akranlarıyla ilişki kurmaları için yardımcı olurum ki çocuk mutsuz olup kendini yalnı hissetmesin diye. Şimdi ben önemsemezsem ihmal etmiş olurum” (Ö5).

Bir gruba ait olma duygusundan yoksun birakma

Çocuğun sosyal gelişiminin önemli bileşenlerinden biri olan aidiyet duygusundan çocuğun çevresindeki birey ya da bireyler tarafından yoksun bırakılması, akranları ya da çevresindeki kişiler tarafından kabul görmemesi ve bu konuda yeterli desteğin sağlanmaması okul öncesi öğretmenleri tarafindan duygusal ihmal olarak yorumlanmaktadır.

"Çocuk bir aileye, bir okula ait olmak ister. Çocuğa ailenin ya da okulda sınıfin bir bireyi olarak bu tür ortamların bir parçası olduğunu, önemsendiğini ve değer verildiğini hissettirmek gerekir. Fakat çocuğun bu tür duygulara sahip olduğunun maalesef çoğu insan farkında değil. Bu nedenle çocuklar ihmal ediliyor" (Ö2).

\section{Okul öncesi öğretmenlerinin cinsel ihmale yönelik algıları}

Araştırmanın altıncı ve son sorusu, okul öncesi öğretmenlerinin cinsel ihmale yönelik algılarının nasıl olduğu yönündedir. Öğretmenlere göre, çocuğun cinsel gelişim ihtiyaçlarının gereken yaş dönemlerinde yeterli düzeyde karşılanmaması sonucunda ortaya çıkan durum, cinsel ihmaldir. Öğretmenlerin cinsel ihmali, cinsel eğitim ihtiyacının ihmali ve cinsel kimlik gelişiminin ihmali olmak üzere iki şekilde algıladıkları görülmektedir. 


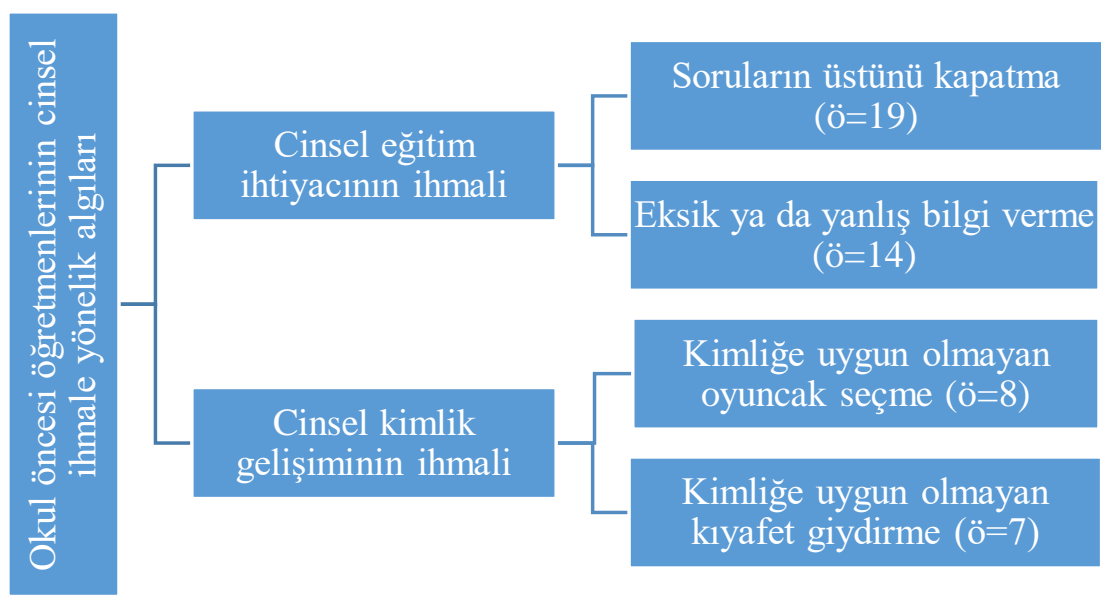

Şekil 8. Okul öncesi öğretmenlerinin cinsel ihmale yönelik algıları (ö: ilgili cevabı veren öğretmen sayısı)

\section{Cinsel eğitim ihtiyacının ihmali}

Okul öncesi öğretmenlerinin cinsel ihmale ilişkin algılarına dair birinci alt kategori, çocuğun gelişimine uygun cinsel eğitim ihtiyacının ihmalini içermektedir. Öğretmenler, çocuğun gelişim seviyesine uygun şekilde öğrenmesi gereken cinsel bilgilerin verilmemesi sonucunda ortaya çıkan durumu, cinsel ihmal olarak yorumlamaktadırlar. Okul öncesi öğretmenlerinin çocuğun gelişiminin bir parçası olan cinsel eğitimin ihmal ya da göz ardı edildiğini düşündüğü davranışlar ise, soruların üstünü kapatma ve eksik ya da yanlı̧̧ bilgi vermedir.

\section{Soruların üstünü kapatma}

Okul öncesi öğretmenleri, çocuğun gelişiminin bir parçası olan cinsel gelişimine yönelik çevresindeki birey ya da bireylere sorular yöneltmesinin ve bu sorulara cevap verilmemesinin veya geçiştirilerek üzerinin kapatılmasının cinsel ihmal olduğunu belirtmektedirler.

“Çocuklar gördüğ̈̈ şeylerden etkileniyorlar, cinsel içerikli durumları merak ediyorlar. Bu durumda direk anlatmak gerekiyor diye düşünüyorum. Hani hangi konuda merak ediyorsa, onu anlatmak ve çocuğun merakını gidermek gerekiyor. Çocuğa bilgi verilmeyip, ihmal edilmesi, üstünün kapatılması daha büyük sorunlara yol açabiliyor" (Ö28).

Eksik ya da yanlış bilgi verme

Öğretmenler, çocuğun bakımından sorumlu birey ya da bireylere cinsel gelişimi ile ilgili sorduğu sorulara, söz konusu kişilerin eksik ya da yanlış şekilde bilgi vermelerinin cinsel ihmal olduğunu ifade etmektedirler.

"Çocuğun belli yaşlarda cinsel eğitimi ile ilgili bilgilerin ebeveynler tarafindan eksik ya da yanlış anlatılması bana ihmali düşündürür. Çocuk gerekli bilgilere sahip değilse arkadaşlarından öğreniyor, teknolojiden öğreniyor, seviyesinin üzerinde yanlış eksik bilgiler ögrenebiliyor. Bu da çocuğun cinsel gelişimine zararlar verebiliyor” (Ö4).

\section{Cinsel kimlik gelişiminin ihmali}

Okul öncesi öğretmenlerinin cinsel ihmale ilişkin algılarına dair ikinci alt kategori, çocuğun cinsel kimlik gelişiminin ihmalidir. Öğretmenler, çocuğun cinsel kimlik gelişimine yönelik yakınındaki birey ya da bireylerin uygun davranışlarda bulunmamasının, çocuğu doğru şekilde yönlendirmemesinin ve özen göstermemesinin, ileriki dönemlerde çocukta davranış bozukluklarına yol açabileceğini ve bundan dolayı çocuğun cinsel gelişiminin ihmal edilmesinin söz konusu olduğunu ifade etmektedir. Katılımcıların, çocuğun cinsel kimlik gelişiminin ihmal 
edildiğini düşündükleri davranışlar ise çocuğun cinsel kimliğine uygun olmayan oyuncak seçilmesi ve cinsel kimliğine uygun olmayan kıyafet giydirilmesi olarak ifade etmişlerdir

\section{Kimliğe uygun olmayan oyuncak seçimi}

Öğretmenler, çocuğun çevresindeki birey ya da bireyler tarafından cinsel kimlik gelişimine uygun oyuncaklar seçilmemesinin ve buna çocuğun doğru şekilde yönlendirilmemesinin çocuğun ileriki yaşantısında problemlere yol açabileceğini dile getirmekte ve bu durumu cinsel ihmal olarak yorumlamaktadırlar.

"Mesela bir kız öğrencim vardı. Sinıfta erkek gibi davranışlarda bulunuyordu. Oyuncak günü araba koleksiyonu yapmış bir sürü araba getirdi. Annesi saçını kısacık kestirmişti. 'Senin evde bebeğin yok mu?' dedim, 'yok sevmiyorum' dedi. Anneyi çağırdım onu da sertçe uyardım, 'saçına, klyafetlerine neden bunlara izin veriyorsunuz?' dedim” (Ö30).

Kimliğe uygun olmayan klyafet giydirme

Öğretmenlerin çocuğun cinsel kimlik gelişimini olumsuz yönde etkilediğini düşündükleri bir diğer bir sorunlu davranış, çocuğa kimliğine uygun olmayan kıyafet giydirilmesidir. Okul öncesi öğretmenleri çocuğun cinsel kimlik gelişimine uygun kıyafetler seçilerek çocuğun doğru şekilde yönlendirilmediği durumları cinsel ihmal olarak yorumlamaktadırlar.

"Çocukları kendi cinsel kimlikleri ile ilgili bilgilendirmek, yönlendirmek gerekiyor. Klz çocuklarını kız gibi, erkek çocuklarını erkek gibi giydirmek gerekir. Buna özen göstermemek ebeveynin ihmalidir" (Ö8).

\section{Tartışma, Sonuç ve Öneriler}

Okul öncesi öğretmenlerinin çocuk istismarı ve ihmaline yönelik algılarının incelendiği bu araştırma sonucunda elde edilen bulgular araştırma soruları doğrultusunda tartışılmıştır. Araştırmanın birinci sorusu, okul öncesi öğretmenlerinin fiziksel istismarı nasıl algıladıklarıdır. Fiziksel istismara yönelik bulgular incelendiğinde, katılımcıların fiziksel istismar algılarının çocuğa yönelik gücü kötüye kullanarak saldırıda bulunma ve bir araç vasıtasıyla saldırıda bulunma davranışlarını içerdiği görülmektedir. Okul öncesi öğretmenlerinin çocuğun çevresindeki birey ya da bireylerin gücünü kötüye kullanarak çocuğa karşı dayak atma, tokat atma, sarsma ve kulak çekme davranışlarında bulunmalarını fiziksel istismar olarak ele aldıkları belirlenmiştir. Öte yandan, uyarı amaçlı, güç uygulamadan sadece kulağından tutarak temasta bulunmanın bazı öğretmenler tarafından istismar olarak algılanmadığı görülmüştür. Söz konusu öğretmenlerin bu davranışı, çocuğun canının acıması durumunu ölçüt alarak değerlendirdikleri belirlenmiştir. Oysaki bu davranışlar çocuklara ceza yöntemi olarak yetişkinler tarafından en kolay kullanılan şiddet türleridir. Literatüre bakıldığında ise, çocukları disipline etmek için kullanılan en eski yöntemlerden biri olan dayağın, kendinden güçlü birey tarafından çocuğa otorite kurmak amacıyla kimi zaman daha doğru davranışlar ya da terbiye yöntemleri uygulamada yetersiz kalınması sebebiyle kullanılan bir davranış olduğu görülmektedir (Saygıl1, 2004). Gözütok (1993) yaptığı çalışmada, öğretmenlerin disiplin sağlamak adına sınıfta tokat atma, vurma, kulak çekme gibi istismar davranışlarında bulunduklarını belirtmiştir. Kefeli'nin (2016) araştırmasında ise, öğretmenlerin sınıf içerisinde çocuğa yönelik yaptıkları istismar davranışları, çocuğu sarsma ve kolundan zorla çekiştirme şeklinde gözlemlenmiştir. Mevcut çalışmada ayrıca sopa, kemer, sigara gibi bir araç vasıtasıyla çocuğun bedeninin herhangi bir bölümüne fiziksel saldırıda bulunma davranışının katılımcılar tarafından fiziksel istismar olarak algılandığı sonucunu ulaşılmıştır. $\mathrm{Bu}$ istismar davranışlarını eğitimciler aynı zamanda fiziksel istismar davranışları içerisinde en ağır dereceli davranışlar olarak nitelendirmektedirler. Literatürde şiddetli bir şekilde çocuğa yapılan elle ve ayakla vurma davranışı, çocuğun bedeninin herhangi bir yerini yakmak, boğmak şeklindeki fiziksel cezalandırmalar, şiddetli fiziksel istismar olarak kabul edilmektedir (Topbaş, 2004). Okul öncesi öğretmenlerinin bu konudaki algılarının net 
olmasının yanı sıra öğretmenlerin bu davranış biçimlerini duymalarından ya da izlerini görmelerinden duygusal olarak etkilendikleri de görünmektedir.

Araştırmanın ikinci sorusu, okul öncesi öğretmenlerinin duygusal istismara yönelik algılarının nasıl olduğudur. Duygusal istismara ilişkin bulgular incelendiğinde, okul öncesi ögretmenlerinin duygusal istismarı, çocuğun duygularına sözel ve davranışsal saldırıda bulunma şeklinde algıladıkları görülmektedir. Öğretmenlerin duygusal istismara ilişkin algılarının birinci boyutu olan sözel saldırıda bulunma, çocuğun kişiliğine yönelik doğrudan ve dolaylı olarak olumsuz söylemlerde bulunma şeklinde ifade edilmiştir. Çocuğu tehdit etme, aşağılama ve kötü sözler söyleme, onun benlik saygısının oluşmasını engelleyici direkt olarak yapılan davranışlar olarak düşünülmektedir. Dolaylı olarak yapılan sözel saldırılar ise, öğretmenler tarafından çocuğu suça teşvik etme ve ayrım ve karşılaştırma yapma davranışları olarak nitelendirilmektedir. Alan yazın incelendiğinde, duygusal istismar çeşitlerinin aşağılama, olumsuz sıfatlar kullanma (Öztürk, 2007), korkutma, y1ldırma ve tehdit etme (Dinleyici ve Dağlı, 2016), ayrım ve karşılaştırma yapma (Öztürk, 2007), olduğu görülmektedir. Şahin (2017) tarafindan gerçekleştirilen araştırmada, öğretmenlerin duygusal istismar türlerine ilişkin algıları arasında aşağılama, dışlama, baskı kurma, ad takma (olumsuz sıfat) davranışlarının yer aldığı görülmüştür. Okul öncesi öğretmenlerinin duygusal istismar algılarının ikinci boyutunu oluşturan çocuğa yönelik davranışsal saldırılar, çocuğun sağlıklı duygusal iletişim bağı kurmasını engelleyici dolaylı ve doğrudan davranışsal eylemler olarak dile getirilmiştir. Öğretmenlerin doğrudan davranışsal saldırı olarak çocuğu yok sayma ve aşırı koruma davranışlarını, dolaylı davranışsal saldırı olarak ise yetişkin rolü verme, izole etme davranışlarını ifade ettikleri görülmüştür. Alanyazında ise reddetme (Dinleyici ve Dağl1, 2016), aşırı koruma (Öztürk, 2007), yalıtma ve ayırma (Iwaniec, 2006), vaktinden önce yetişkin rolü verme (Siyez, 2003), yok sayma (Bayraktar, 1990) davranışlarının duygusal istismar çeşitleri olarak ele alındığı görülmektedir. Şahin'in (2017) araştırmasında da benzer şekilde öğretmenler yok sayma, dışlama, kategorize etme, duygusal tepki vermeyi reddetme, ilgisizlik davranışlarını duygusal istismar olarak algılamaktadır. Sonuç olarak bu araştırma kapsamında elde edilen bulgular ile alan yazında bu kavramlara ilişkin ulaşılan bulguların birbiriyle örtüşmekte olduğu ve okul öncesi öğretmenlerinin duygusal istismar anlayışlarının alanyazında ortaya konan çerçeve ile paralel olduğu söylenebilir. Öte yandan, öğretmenler, sınıfta düzeni sağlamak adına çocuğu düşünme sandalyesine oturtma (izole etme) ve sevdiği şeyden mahrum bırakma şeklinde uygulamalar gerçekleştirdiklerini ifade etmişlerdir. İlgili alanyazın incelendiğinde bunların duygusal istismar olarak nitelendirilen davranışlar olduğu ve sıkça kullanıldığı görülmektedir. Alkan (2007) çalışmasında, öğretmenlerin istenmeyen davranışlara karşı en fazla kullandıkları yöntemlerden birinin davranışların sonuçları hakkında düşünmesini sağlama, öğrenciyi tahtada bekletme ve öğrenciyi sevdiği şeylerden ve eğlenceli etkinliklerden mahrum bırakma şeklinde olduğunu saptamıştır.

Araştırmanın üçüncü sorusu, okul öncesi öğretmenlerinin cinsel istismarı nasıl algıladıkları yönündedir. Araştırmadan elde edilen bulgular, öğretmenlerin cinsel istismar olgusunu, çocuğa yapılan temas içeren cinsel saldırılar ve temas içermeyen cinsel saldırılar olmak üzere iki kategoride algıladıkları görülmektedir. Çocuğa temas içeren cinsel saldırılar, eğitimciler tarafından özel alanlarına dokunma ve kötü niyetle bedene dokunma şeklinde algılanmaktadır. Çocuk cinsel istismarı aynı zamanda, ergen veya çocuğa yönelik baskı ya da zorlama sonucunda oluşan cinsel temastır (Kaufman, Barber, Mosher ve Carter, 2002). Özel alanlara dokunma öğretmenler tarafından cinsel içerikli dokunmalar olarak tanımlanan taciz, tecavüz davranışlarını da içermektedir. Akacan'ın (2012) çalışmasında da öğretmenler okul ortamında öğrencilerin cinsel istismara maruz kaldıklarını belirtmiş ve cinsel içerikli davranışlardan birinin, erkek öğrencilerin kız öğrencilerin cinsel organına dokunmaları şeklinde olduğunu belirtmişlerdir. Bedenin herhangi bir bölümüne cinsel haz almaya yönelik yapılan kötü dokunmada ise öğretmenler, çocuğa cinsel haz almaya yönelik yapılan, bedeninin herhangi bir yerine basit dokunuşlarda olsa yapılan bütün dokunmaların cinsel istismar olduğunu ifade etmişlerdir. Gries, Goh ve Cavanaugh'un (1997) yaptıkları araştırmada, cinsel istismara uğrayan çocuklar tarafindan bildirilen cinsel istismar türleri arasında, okşama ve faile dokunmaya zorlamanın en fazla 
karşılaşılan istismar davranışları olduğu belirtilmiştir. Schultz (1990) ise, çocuğun cinsel olmayan organlarına cinsel haz almak amacıyla yapılan bütün dokunmaları cinsel istismar sayılabilecek davranışlar içerisinde tanımlamaktadır. Mevcut araştırmada, okul öncesi öğretmenlerinin cinsel istismar kavramı ve türlerine ilişkin elde edilen bulguların, alanyazınla örtüştüğü görülmektedir.

Araştırmanın dördüncü sorusu, öğretmenlerin fiziksel ihmali nasıl algıladıklarıdır. Araştırmadan elde edilen bulgular, öğretmenlerin fiziksel ihmal olarak çocuğun temel gereksinimlerinin yetersiz karşılanmasını ve fiziksel koşullarının yetersizliğini algıladıkları görülmektedir. Okul öncesi öğretmenleri en sık karşılaştıkları ihmal davranışları olarak temizlik, beslenme, giyinme ve sağlık ihtiyaçlarının çocuğun bakımından sorumlu kişiler tarafindan yetersiz yapılması ya da hiç yapılmaması şeklinde ifade etmişlerdir. Çocuğun okula banyosuz, elyüz temizliğinin ve saç bakımının yapılmadan gönderilmesi en fazla görülen ihmal davranışları arasındadır. Öğretmenlere göre, beslenme konusu ile ilgili ebeveynlerin en çok ihmal ettikleri nokta, çocukların hazır gıdalara yönlendirilerek sağlıksız yiyecekler yemeye maruz bırakılmalarıdır. Mevsime elverişsiz ya da özensiz kıyafetler giydirme ise diğer bir fiziksel ihmal davranışı olarak değerlendirilirken, sağlık konusunda öğretmenlerin çok sık karşılaştıkları ve ihmal olarak nitelendirdikleri durum ise, çocuğun hastayken ilaçları ile birlikte 1srarla okula gönderilmesidir. Çocukların fiziksel ihmale uğraması, çocuğun bedensel olarak zarar görmesinin yanında akranları arasında da çeşitli problemlere sebep olmaktadır. Okula düzenli, temiz ve yeterli kıyafet ile gönderilmemiş çocuk, arkadaşları tarafından dışlanabilmekte ve bunun sonucunda okuldan kaçma davranışı gösterebilmektedir (Horwath, 2007).

Araştırma sorularından beşincisi, okul öncesi öğretmenlerinin duygusal ihmali nasıl algıladıkları yönündedir. Öğretmenlerin, çocuğun psikolojik ve ruhsal gereksinimlerinden yoksun bırakılmasını ve sosyal gereksinimlerinin karşılanmamasını duygusal ihmal olarak nitelendirildikleri görülmektedir. Öğretmenlere göre çocuğa yeterli sevgi göstermeme, yani sevgiden yoksun bırakma ve çocuğu önemsememe en sik karşılaşılan duygusal ihmal davranışlarıdır. SHÇEK ve UNICEF'in (2010) ülkemizde çocuk istismarı ve aile içi şiddet konulu çalışmasında, 7-14 yaş aralığında bulunan kız çocukları ihtiyaçlarını ihmal eden kişilerin çoğunlukla ebeveynleri ve öğretmenleri olduğu, en çok maruz kaldıkları ihmal davranışının ise sevgisizlik, sevgi göstermeme olduğu belirtilmiştir. Duygusal istismarla karşılaşan çocukların ebeveynlerinin gösterdiği duygusal tutumlar bazı duygusal ifadelerle ölçülebilmektedir. $\mathrm{Bu}$ ifadelerden biri aşırı koruyucu ifadelerdir (Tarrier ve Calam, 2002). Öğretmenler, duygusal istismar kategorisinde değerlendirilmekte olan çocuklara karşı ebeveynlerin takındığı aşırı koruyucu tutumun da duygusal ihmal olduğunu belirtmektedirler. Aşırı koruyucu ebeveynler, her konuda çocuklarını korumak isteyerek, çocuğun kendi başına yapabileceği şeyleri dahi kendileri yaparak firsat vermemektedirler (Atauz, 1991). Bunun sonucunda, özgüven duygusundan yoksun çocuklar yetişmekte olduğundan dolayı öğretmenler çocuğun güven duygusunun ihmal edildiğini düşünmekte ve duygusal ihmal olarak belirtmektedirler. Çocuğun çevresindeki birey ya da bireyler tarafından arkadaş edinmesinden, ilişkiler kurarak sosyalleşmesinden ve bir gruba ait olma duygusundan çeşitli nedenlerle yoksun bırakılması da öğretmenler tarafından duygusal ihmal olarak algılanmaktadır. Çocuğun sosyalleşmesinin duygusal temel gereksinimlerinden biri olduğu ve sosyal gereksiniminin yeterli şekilde karşılanmamasının duygusal ihmal olduğu literatür tarafindan da desteklenmekte (Cüceloğlu, 1997; Holt, Finkelhor ve Kantor, 2007; Polat, 2005) ve çocuğun sosyalleşme sürecinde çevreyle etkileşiminde yardımcı olabilecek ve iletişim kurabileceği ortamların sağlanmasının duygusal ihtiyaçlarının bir parçası olduğu vurgulanmaktadır (Polat, 2001).

Araştırma sorularının altıncı ve sonuncusu, okul öncesi öğretmenlerinin cinsel ihmale yönelik algılarının nasıl olduğudur. Araştırmadan elde edilen bulgular, öğretmenlerin çocuğun cinsel gelişimine uygun bilgilerin verilmemesini cinsel ihmal olarak değerlendirdiklerini göstermektedir. Bunun yanında, özellikle okul öncesi dönemde çocuğun cinsel kimliğine uygun giydirilmemesi ve oyuncak seçiminin yapılmaması, cinsel ihmal olarak nitelendirilmektedir. Alanyazında ise, çocuğun cinsel kimliğine uygun davranışlarda bulunulmaması ve çocuğun kimliğine uygun şekilde giydirilmemesi (Altunsu, 2004), gereken zamanda gerekli cinsel eğitimin verilmemesi (Altınsu, 2004; Aral, 1997; Karaman, 1993; Yaşar ve Akduman, 2007) şeklindeki 
davranışlar çocuğun cinsel ihmali olarak ele alınmaktadır. Dolayısıyla, örneklemdeki öğretmenlerin çocukların cinsel istismarı ile ilgili algılarının ilgili alanyazınla paralellik gösterdiği görülmektedir.

Sonuç olarak, okul öncesi öğretmenlerinin çocuk istismarı ve ihmali konusunda bir takım bilgilerinin ve duyarlılıklarının olduğu fakat bilgilerinin yetersiz olduğu sonucuna ulaşılmıştır. Öğretmenler, çocukların daha çok ev ortamında bakımından sorumlu ve yakınındaki kişiler tarafından istismar ve ihmale uğradıklarını düşünmektedirler. Fiziksel istismar deyince, ögretmenlerin neredeyse yarısının aklına ilk olarak cinsel istismar gelmektedir. Kulak çekme davranışını bazı eğitimciler doğrudan fiziksel istismar olarak değerlendirirken, bazılarının ise davranışın şiddetine ve yapılış şekline göre değerlendirme yaptıkları sonucuna ulaşılmıştır. Bir araç vasıtasıyla saldırıda bulunma davranışını öğretmenler, en şiddetli fiziksel istismar türü olarak değerlendirmektedirler. Ayrıca, okul öncesi öğretmenleri sınıf düzenini sağlamak adına sevdiği şeyden mahrum bırakma ve düşünme sandalyesine oturtma (izole etme) gibi bir takım uygulamalara yer verdikleri, öte yandan bu davranışların da aslında birer duygusal istismar davranış1 olduğu görülmüştür. Okul öncesi öğretmenlerinin cinsel istismara yönelik temas içeren cinsel içerikli davranışların yanında temas içermeyen cinsel içerikli davranışları da cinsel istismar olarak algıladıkları sonucuna ulaşılmıştır. Okul öncesi öğretmenlerinin çocuk ihmaline yönelik bilgi ve farkındalık seviyelerinin çocuk istismarına göre daha az olduğu, çocuk istismarını çocuk ihmalinden daha iyi açıkladıkları belirlenmiştir.

Katılımcılar, fiziksel ihmal olarak çocuğun gereksinimlerinin yetersiz karşılanmasını ve fiziksel koşulların yetersizliğini görmektedirler. Öğretmenlerin en sık karşılaştıkları ihmal davranışlarının temizlik, beslenme, giyinme ve sağlık ihtiyaçlarının çocuğun bakımından sorumlu kişiler tarafından yetersiz yapılması ya da hiç yapılmamasını olduğu tespit edilmiştir. Öğretmenlerin duygusal ihmale yönelik algılarını ise, çocuğu sevgiden yoksun bırakma ve çocuğa aşırı koruyucu tutum oluşturmaktadır. Son olarak, okul öncesi öğretmenleri cinsel ihmali, çocuğun cinsel gelişimine uygun bilgi ve gereksinimlerden yoksun bırakılması olarak nitelendirmektedirler.

Araştırma sonuçları dikkate alındığında, öğretmenlere düzenli şekilde çocuk istismarı ve ihmali ile ilgili hizmet içi eğitimler, seminerler, sempozyum ve konferanslar düzenlenmesi yararlı olacaktır. Söz konusu faaliyetlerde özellikle fiziksel ve duygusal cezanın disiplin yöntemi olarak kullanılmaması gerektiği üzerinde durulabilir. Gelecekte yapılacak araştırmalarda, çocuk istismarı ya da ihmalinin alt boyutlarından (fiziksel, duygusal veya cinsel) birine odaklanılabilir. Konuyla ilgili farklı meslek gruplarıyla çocuk istismarı ve ihmali ile ilgili fenomolojik çalışmalar gerçekleştirilebilir.

\section{Kaynaklar}

Akacan, B. (2012). Ortaöğretim okullarında görev yapan eğitimcilerin çocuk istismarına ilişkin görüşleri. Turkish International Journal of Special Education and Guidance and Counceling, 1(2), 37-53.

Alkan, H. B. (2007). İlköğretim öğretmenlerinin istenmeyen davranışlarla baş etme yöntemleri ve okulda şiddet (Yayımlanmamış yüksek lisans tezi). Niğde Ömer Halisdemir Üniversitesi, Niğde.

Altunsu, B. (2004). Çocuklara bakım veren hemşirelerin çocuk istismar ve ihmalini tanımlayabilmeleri (Yayımlanmış yüksek lisans tezi). Marmara Üniversitesi, İstanbul.

Aral, N. (1997). Fiziksel istismar ve çocuk. Ankara: Tekışık veb Ofset.

Atauz, S. (1991). Kitle iletişim araçlarında çocuk istismarı ve ihmali. Çocukların Kötü Muameleden Korunması 1. Ulusal Kongresi Bildiri Kitabı, içinde (ss.233-243). Ankara: Gözde Repro Ofset.

Baginsky, M. (2003). Newly qualified teachers and child protection: A survey of their views, training and experiences. Child Abuse Review, 12, 119-127.

Bayraktar, N. (1990). Defining subcategories of psychological maltreatment (Yayımlanmamış yüksek lisans tezi). Boğaziçi Üniversitesi, İstanbul. 
Benbenishty, R., Zeira, A. ve Astor, R. A. (2002). Children's reports of emotional physica and sexual maltreatment by educational staff in Israel. Child Abuse \& Neglect, 26, 763-782.

Beyazova, U. ve Şahin, F. (2001). Çocuğun şiddetten korunma hakkı. Milli Eğitim Dergisi, 151, 90-94.

Creswell, J. W. (2007). Qualitative inquiry and research design: Choosing among five traditions (second edition). London: Sage.

Cüceloğlu, D. (1997). İçimizdeki çocuk. İstanbul: Remzi Kitabevi.

Dinleyici, M. ve Dağl1, F. (2016). Duygusal ihmal, istismar ve çocuk hekiminin rolü. Osmangazi Tip Dergisi, 38(2), 18-27.

Dönmez, B. E. (2009). Okul öncesi eğitim ögretmenleri ve velilerin çocuk istismarl ve ihmaline yönelik görüşleri (Yayımlanmamış yüksek lisans tezi). Selçuk Üniversitesi, Konya.

Erermiş, S. (2001). Çocuk ihmali nedir? İzmir Atatürk Hastanesi Tıp Dergisi, 39(2), 710.

Erginer, F. (2007). Ankara ili ilköğretim okulu yöneticilerinin ögrencilerin aileleri tarafindan istismarl ve ihmaline ilişskin görüşleri (Yayımlanmamış yüksek lisans tezi). Ankara Üniversitesi, Ankara.

Erol, D. (2007). Okul öncesi ĕgitim kurumlarında görev yapan öğretmenlerin çocuklardaki fiziksel istismar belirtilerine ilişkin farkındalıkları (Yayımlanmamış yüksek lisans tezi). Anadolu Üniversitesi, Eskişehir.

Gökler, R. (2006). Eğitimde çocuk istismarı ve ihmaline genel bir bakış. Türkiye Sosyal Araştırmalar Dergisi, 3, 47-76.

Gözütok, F. D. (1993). Okulda dayak. Ankara: Ankara Üniversitesi Eğitim Bilimleri Yayınları.

Gries, L. T., Goh, D. S. ve Cavanaugh, J. (1997). Factors associated with disclosure during child sexual abuse assessment. Child Sex Abuse, 5(3), 1-19.

Herman, M., Brown, G., Verbiest, S., Carlson, P., Hooten, E. ve Howell, E. (1999). Under ascertainment of child abuse mortality in the United States. Journal of the American Medical Association, 282(5), 463-467.

Holt, M. K., Finkelhor, D. ve Kantor, G. K. (2007). Multiple victimization experiences of urban elementary school students: Associations with psychosocial functioning and academic performance. Child Abuse \& Neglect, 31(5), 503-515.

Horwath, J. (2007). Child neglect: Identification and assessment. Basingstok: Palgrave Macmillan.

Iwaniec, D. (2006). The emotionally abused and neglected child: Identification, assessment and intervention. New York: John Wiley \& Sons.

Johnson, B. ve Christensen, L. (2008). Educational research: Quantitative, qualitative, and mixed approaches. Thousand Oaks, California: Sage Publishing.

Johnson, C. (1996). Abuse and neglect of children. W. E. Nelson, R. E. Behrman, R. M. Kliegman ve A. M. Arvin (Yay. haz.), Textbook of Pediatrics içinde (ss. 121-131). Philadelphia: WB Saunders Company.

Johnson, R. B. (1997). Examining the validitiy structive of qualitative research. Education, $118(2), 282-292$.

Kara, B., Biçer, Ü. ve Gökalp, A. S. (2004). Çocuk İstismarı. Çocuk Sağlı̆̆ı ve Hastalıkları Dergisi, 47, 140-151.

Karaman, Y. (1993). İlkokul öğretmenlerinin gözlemlerine göre çocukların aileleri tarafindan istismarl ve ihmali (Yayımlanmamış yüksek lisans tezi). Hacettepe Üniversitesi, Ankara.

Kaufman, K., Barber, M., Mosher, H. ve Carter, M. (2002). Reconceptualizing child sexual abuse as a public health concern. P. A. Schewe (Yay. haz.), Preventing Violence in Relationships: Interventions Across The Life Span içinde (ss.27-54). Washington, D. C: American Psychological Association.

Kefeli, H. (2016). Okul öncesi öğretmenlerinin çocuk istismarı ve ihmali davranışları ile kurum personelinin konuya ilişkin görüşleri (Yayımlanmamış yüksek lisans tezi). Ankara Üniversitesi, Ankara.

Kenny, M. (2001). Child abuse reporting: Teachers' perceived deterrents. Child Abuse and Neglect, 25, 81-92. 
Kenny, M. C. ve McEachern, A. G. (2008). Reporting suspected child abuse: A pilot comparison of middle and high school counselors and principals. Journal of Child Sexual Abuse, 11(2), 59-75.

Khoury-Kassabri, M. (2009). The relationship between staff maltreatment of students and bullyvictim group membership. Child Abuse \& Neglect, 33, 914-923.

Kim, D., Kim, K., Park, Y., Zhang, L. D. ve Lu, M. K. (2000). Children's experience of violence in China and Korea: A transcultural study. Child Abuse \& Neglect, 24(9),1163-1173.

Kutchinsky, B. (1999). Çocuğun cinsel istismarı: Yaygınlık, müdahale ve önleme genel bir bakış. İ. Konanç, İ. Gürkaynak ve A. Egemen (Yay. haz.), Çocuk İstismarı ve İhmali içinde (ss. 163-175). Ankara: Çocuk İstismarını ve İhmalini Önleme Derneği Yayınları.

Neuman, W. L. (2007). Toplumsal araştırma yöntemleri (S. Özge, Çev.). İstanbul: Yayınodası.

O'Toole, R., Webster, S., Lucal, B. ve O'Toole, A. (1999). Teachers' recognation and reporting of child abuse: A factorial survey. Child Abuse and Neglect, 23(11), 1083-1101.

Öztürk, S. (2007). Çocuklarda duygusal istismar (Yayımlanmamış yüksek lisans tezi). Fırat Üniversitesi, Elazığ.

Polat, O. (2001). Cinsel istismar. Çocuk ve şiddet. İstanbul: Der Yayınları.

Polat, O. (2005). Çocuk istismarı ve Türkiye'deki durumu. Klinik Çocuk Forumu, 1-11.

Patton, M. Q. (2014). Nitel araştırma ve değerlendirme yöntemleri (M. Bütün-S. B. Demir, Çev.). Ankara: Pegem Akademi.

Reece, R. M. (1997). Background considerations in child maltreatment. Child Maltreatment Mosby, 666-916.

Runyan, D., Wattam, C., Ikeda, R., Hassan, F. ve Ramiro, L. (2002). Child abuse and neglect by parents and other carevigers. E. G. Krug, L. L. Dahlberg, J. A. Mercy, A. B. Zwi ve R. Lozano (Yay. haz.), Word Report on Violence and Health, içinde (ss. 57-86). Geneva: World Health Organization.

Sarıbaş, A. K. (2013). Okul öncesi ögretmenlerinin çocuk istismarına yönelik farkındalıklarının belirlenmesi (Yayımlanmamıș yüksek lisans tezi). Çanakkale Onsekiz Mart Üniversitesi, Çanakkale.

Saygıl1, S. (2004). Çocuklarda davranış bozuklukları. İstanbul: Elit Yayınları.

Schultz, R. (1990). Secret of adolescence: Incest and developmental fixations. Incest related syndromes of adult psychopathology. Washington, D.C: American Psychiatric Press.

Siyez, D. M. (2003). Duygusal istismara maruz kalan ve kalmayan ergenlerin benlik algıları ile depresyon ve kaygı düzeylerinin karşılaştırılması (Yayımlanmamış yüksek lisans tezi). Dokuz Eylül Üniversitesi, İzmir.

Şahin, İ. (2017). Ĕgitim kurumlarında duygusal istismar ve yansımaları: Nitel bir çalışma (Yayımlanmamış yüksek lisans tezi). Çukurova Üniversitesi, Adana.

SHÇEK ve UNICEF (2010). Türkiye'de çocuk istismarı ve aile içi şiddet araştırması. Özet rapor. Erişim adresi: atud.org.tr/kutuphane/unisefrapor.pdf

Tarrier, N. ve Calam, R. (2002). New developments in cognitive-behavioural case formulation. Epidemiological, systemic and social context: An integrative approach. Behavioural and Cognitive Psychotherapy, 30(3), 311-328.

Theoklitou, D., Kabitsis, N. ve Kabitsi, A. (2012). Physical and emotional abuse primary school children by teachers. Child Abuse \& Neglect, 36, 64-70.

Topbaş, M. (2004). İnsanlığın büyük bir ayıbı: Çocuk istismarı. TSK Koruyucu Hekimlik Bülteni, $3(4), 76-80$.

Toros, K. ve Tiirik, R. (2016). Preschool teachers' perceptions about and experience with child abuse and neglect. Early Childhood Education Journal, 44(1), 21-30.

Tugay, D. (2008). Ögrretmenlerin çocuk istismarı ve ihmaline yönelik bilgi düzeyleri (Yayımlanmamıs yüksek lisans tezi). Marmara Üniversitesi, İstanbul.

Türkiye'de Çocuk İstismarı Raporu-2 (2018). Türkiye'de çocuk istismarı. Erişim adresi: http://imdat.org/wp-content/uploads/2018/04/RAPOR-ÇOCUK-İSTISMARI-tam_v2_ cleancopy.pdf. 
Walsh, K. ve Farrell, A. (2008). Identifying and evaluating teachers' knowledge in relation to child abuse and neglect: A qualitative study with Australian early childhood teachers. Teaching and Teacher Education, 24(3), 585-600.

Wekerle, C., Miller A. L., Wolfe, D. A. ve Spindel, B. C. (2006). Childhood maltreatment. Boston: Hogrefe and Huber Publishers.

WHO (2002). World report on violence and healt: Child abuse and neglect by parents and other caregivers. Geneva. Erişim adresi: http://whqlibdoc.who.int/publications/2006/92415 94365_eng.pdf.

Yaşar, Z. F. ve Akduman, G. G. (2007). Child abuse-neglect and forensic odontology. TAF Prev Med Bull, 6, 389-394.

Yıldırım, K. (2010). Nitel araştırmalarda niteliği arttırma. İlköğretim Online, 9(1), 79-92.

Yıldırım, A. ve Şimşek, H. (2008). Nitel araştırma yöntemleri. Ankara: Seçkin Yayıncılık.

\section{Extended Abstract}

\section{Introduction}

In order for a society to build its future on solid grounds and to make progress, children need to grow up physically, spiritually and physically healthy. It is possible for an individual to spend the preschool years which constitute an important stage of growth, development, maturation and personality development in a healthy and productive manner with a qualified preschool education besides the education given in the family. In this respect, preschool education institutions, especially preschool teachers, have an important role in recognizing and preventing all types of abuse. (Baginsky, 2003). Teachers are the ones who spend the most time with their children and their families. Therefore, teachers have critical duties to identify and protect children who have been abused and neglected. (Erol, 2007).

Child abuse is defined as deliberate or unintentional behavior by a person, society or country that negatively affects the child's health, physical and psychosocial development; child neglect is defined as the inability of the person responsible for the child to provide the vital needs of the child such as nutrition, shelter, health and supervision. There are three types of abuse and neglect: physical, emotional and sexual.

Child abuse and neglect has been an important topic for many years. When the international literature is examined, it is seen that teachers' experiences and opinions about child abuse and neglect (Toros \& Tiirik, 2006; Walsh \& Farrell, 2008) and studies on reporting and reporting of abuse by teachers (Kenny, 2001; O'Toole, Webster, O'Toole \& Lucal, 1999; Toros $\&$ Tiirik, 2006). The results of these studies show that teachers do not have sufficient knowledge and experience about child abuse and neglect, and they feel that they feel inadequate in awareness and reporting, and that they experience trust problems.

When analyzed the studies in Turkey, there are a number of studies on preschool teachers' awareness about child abuse and neglect (Dönmez, 2009; Erol, 2007; Sarıbaş; 2013; Tugay, 2008). The findings of these studies demonstrate that preschool teachers do not have sufficient information about child abuse and neglect and that there are deficiencies in reporting. In the other hand, in these studies, various questionnaires were used as data collection tools. Such a method allows data collection from larger samples, but has some limitations in obtaining in-depth information. For this reason, Kefeli (2016) conducted an observation and interview study in order to determine the views of preschool education staff about child abuse and neglect and the abuse and neglect of preschool teachers in the classroom. As a result of the study, it was concluded that the school staff did not have the necessary level of knowledge about child abuse and neglect, and that the preschool teachers' thoughts about the abuse contradicted their behaviors in the classroom.

On the other hand, the rate of child abuse and neglect is twice as high in preschool years as in older age groups (WHO, 2002). Therefore, the awareness of preschool teachers on this problem is very important. Providing informative and preventive counseling to preschool teachers about child abuse and neglect can play an important role in preventing child abuse and neglect, early diagnosis and effectively coping with the situation. In order to carry out such an activity, 
first of all, teachers' current perceptions of child abuse and neglect should be known. Considering the limitation of qualitative studies aimed at revealing the perceptions of preschool teachers about child abuse and neglect in our country, in this study, perceptions of preschool teachers about child abuse and neglect were investigated.

\section{Method}

In this study, the phenomenology pattern was used to reveal the perceptions of preschool teachers about how they perceived, understood, interpreted and interpreted child abuse and neglect. The study group consists of 36 preschool teachers working in Gaziantep city center. In the study, semistructured interview form, prepared by the researchers, was used as a data collection tool. A comprehensive literature review was conducted to prepare appropriate interview questions. As a result of the literature study, six general themes were identified and a semi-structured interview form consisting of seven questions was formed in parallel with these general themes. The form was presented to three faculty members who were experts in preschool education and qualitative research. Interview questions were reorganized in line with the expert opinion and the purpose of the research. In the next step, two preschool teachers were piloted to evaluate the comprehensibility and appropriateness of the questions in the interview form and the interview form was finalized. The interview data obtained within the scope of the research were analyzed using content and descriptive analysis from qualitative data analysis.

\section{Result and Discussion}

It was found that preschool teachers had some knowledge and sensitivity about child abuse and neglect but their knowledge was insufficient. Teachers believed that children were often abused and neglected by people who are responsible for their care in the home environment. When it comes to physical abuse, almost half of the teachers thought of sexual abuse first. It was concluded that while some teachers perceived ear pulling behavior as direct physical abuse, others assessed it according to the severity and manner of conduct of the behavior. Teachers perceived the attack behavior through a tool as the most severe form of physical abuse. In addition, it was observed that preschool teachers used some methods such as depriving them of what they liked in order to maintain the order of the classroom and putting them in the chair of thinking (isolation), while these behaviors were actually emotional abuse behaviors. In addition, it was found that preschool teachers perceived contact sexual behaviors as abuse, as well as contactless sexual behaviors. Preschool teachers' level of knowledge and awareness about child neglect was lower than child abuse and they explained child abuse better than child neglect.

The participants explained physical neglect as inability to meet the needs of the child. The most common neglect behaviors faced by the teachers were that children's needs such as nutrition, cleaning and dressing were not adequately met by their parents. Teachers considered parents' irrelevant or excessive caring behavior as emotional neglect. Finally, preschool teachers defined sexual neglect as not giving the child appropriate information for sexual development. 